\begin{tabular}{|c|c|}
\hline $\begin{array}{l}\text { Additional } \\
\text { Information }\end{array}$ & $\begin{array}{l}\text { NOTICE: This is the author's version of a work that was accepted for } \\
\text { publication in Chemical Engineering Research and Design. Changes } \\
\text { resulting from the publishing process, such as peer review, editing, } \\
\text { corrections, structural formatting, and other quality control mechanisms } \\
\text { may not be reflected in this document. Changes may have been made to } \\
\text { this work since it was submitted for publication. A definitive version was } \\
\text { subsequently published in Chemical Engineering Research and Design, } \\
\text { Vol. } 91 \text {, Issue } 9,(2013) \text {. } \\
\text { doi: http://dx.doi.org/10.1016/j.cherd.2013.04.004 }\end{array}$ \\
\hline
\end{tabular}




\section{Modelling and Numerical Simulation of Liquid-Solid Circulating Fluidized Bed System for Protein Purification}

Pei Wen Lau, ${ }^{1}$ Ranjeet Utikar, ${ }^{1 *}$ Vishnu Pareek, ${ }^{1}$ Stuart Johnson, ${ }^{2}$ Sandeep Kale, ${ }^{3}$ Arvind Lali, $^{3}$

${ }^{1}$ Department of Chemical Engineering, Curtin University, Perth, Western Australia

${ }^{2}$ School of Public Health, Curtin Health Innovation Research Institute, Curtin University, Perth, Western Australia

${ }^{3}$ Center of Energy Biosciences Department, Institute of Chemical Technology, Mumbai, India

${ }^{*}$ Corresponding Author:

Dr Ranjeet Utikar

Department of Chemical Engineering

Faculty of Science and Engineering

School of Chemical and Petroleum Engineering

Curtin University, Perth, Western Australia 6102

Tel: (+618) 92669837

Fax: (+618) 92662681

E-mail: r.utikar@curtin.edu.au 


\section{Abstract:}

A novel liquid-solid circulating fluidized bed (LSCFB) was modelled for protein recovery from the feed broth. A typical LSCFB system consists of downer and riser, integrating two different operations simultaneously. A general purpose, extensible, and dynamic model was written based on the tanks-in-series framework. The model allowed adjusting the degree of backmixing in each phase for both columns. The model was validated with previously published data on extraction of bovine serum albumin (BSA) as model protein. Detailed dynamic analysis was performed on the protein recovery operation. The interaction between the riser and downer were captured. Parametric studies on protein recovery in LSCFB system were carried out using the validated model to better understand the system behaviour. Simulation results have shown that both production rate and overall recovery increased with solids circulation rate, superficial liquid velocity in the downer and riser, and feed solution concentration. The model was flexible and could use various forms of ion exchange kinetics and could simulate different hydrodynamic behaviours. It was useful to gain insight into protein recovery processes. The general nature of the model made it useful to study other protein recovery operations for plant and animal proteins. It could also be useful for further multi-objective optimization studies to optimize the LSCFB system.

Keywords: Adsorption, liquid-solid circulating fluidized bed (LSCFB), dynamic modelling, dynamic simulation, protein recovery, tanks-in-series 


\section{Introduction}

Liquid-solid circulating fluidized bed (LSCFB) systems are rapidly being applied in biochemical separation technology $[13,14]$. Typical LSCFB systems consist of two parts viz. a downer and a riser, integrating principal reactions or adsorption processes with continuous circulation of solid particles between these two. Typically, the downer is used is used for reaction or adsorption process to provide a longer residence time. Whereas, the riser, with its higher liquid velocity and excellent plug flow characteristics, is used for fast desorption or regeneration of adsorbents. Lan et al. $[6,8]$ introduced the concept of LSCFB for adsorption processes. They studied the effect of operating conditions on the hydrodynamics of LSCFB and developed LSCFB systems for the continuous recovery of bovine serum albumin (BSA) and whey proteins from unclarified broths using Diaion HPA25 ${ }^{\circledR}$ anion ion exchangers. Patel et al. [13] developed an LSCFB system with anoxic and aerobic beds for simultaneous removal of carbon, nitrogen and phosphorus from municipal wastewater. While these studies have demonstrated that such LSCFB adsorption have potential applications, these systems are still poorly understood. Other than all the benefits of fluidization, including low and stable pressure drops across the fluidized beds, this technology has attracted attention for its enhanced mass and heat transfer, reduced backmixing, and easy handling of particles of mixed sizes and densities lead to a much more effective processing [18]. Besides, the riser-downer configuration of LSCFB system makes it possible to have continuous processes with adsorption and desorption conducted simultaneously, further enhancing the efficiency and equipment size reduction [1, 8]. Overall, LSCFB systems have advantages of economy; however their success is strongly dependent on better understanding of the LSCFB dynamics.

In this paper, the application of LSCFB system for continuous protein recovery was studied. A general purpose, extensible, and dynamic mathematical model based on the tanks-in-series approach was established. The model allows for adjustment of the backmixing degree in each 
phase (solid and liquid) for both riser and downer and therefore providing flexibility to match the residence time distribution of industrial systems. The model predictions were validated using the available experimental data on the BSA recovery onto Diaion HPA2 $5^{\circledR}$ using the LSCFB system [9]. The validated model was then utilised to study the effects of various parameters on LSCFB performance.

\section{Protein Recovery Using LSCFB}

A schematic diagram of the LSCFB system is shown in Fig.1 [11]. The LSCFB was configured by two interconnected fluidized beds, namely a downer and a riser. Other important components of LSCFB involved a liquid-solid separator, a measurement device of solid circulation rate, a solid return pipe, a top washing section, an inclined solid feed pipe, and a bottom washing section. In this study, the downer was of $120 \mathrm{~mm}$ i.d. and $2.5 \mathrm{~m}$ height, while the riser was $3 \mathrm{~m}$ in height and $38 \mathrm{~mm}$ in diameter. The cross-sectional area ratio of riser to that of the downer were 10.

Lan et al. [6, 9] investigated continuous recovery of BSA to polymeric adsorbents Diaion HPA $25^{\circledR}$. The synthetic adsorbent particles which had an average size of $0.32 \mathrm{~mm}$ diameter were applied into the system. The continuous protein adsorption was conducted with downer as the adsorption vessel; whereas, the riser was used for regeneration of adsorbents. The downer operates in conventional fluidization regime, and in this study the liquid velocity was kept below the particle terminal settling velocity but enough to fluidize the particles. In the downer, the liquid and solid phases were kept in counter-current contact. The feed stream was injected through a distributor into the bottom of the downer, and the solid particles moved down counter-currently to the rising feed stream. The particles then travelled from downer to the bottom of riser through solids feed pipe. The riser was a fast fluidization vessel wherein the primary and auxiliary liquid streams were injected into the bottom of the riser. The function of auxiliary liquid stream through 
the liquid distributor was to stir up particles at the bottom of the riser whereas the primary liquid stream was introduced into the riser to transport the particles. The riser operated at a total liquid velocity higher than the particle terminal settling velocity. The two phases moved co-currently to the top of the riser and then separated within the liquid-solid separator. The particles were then transferred from the riser to the top of the downer via the solids return pipe.

As discussed previously, in a continuous protein recovery process, both downer and riser contained two liquid solutions of different properties, i.e. the feed solution contained $2 \mathrm{~g} / \mathrm{L} \mathrm{BSA}$, whereas the extracting buffer contained $0.4 \mathrm{M}$ salt solution. Both solutions were prepared in 10 $\mathrm{mM}, \mathrm{pH} 7.0$ phosphate buffer. LSCFB handled these liquid streams independently as dynamic seals were provided by solids feed pipe and return pipe in between the columns by maintaining the pipes in moving packed bed regime. The wash water flows were essential in establishing the dynamic seals.

Judicious pressure balance has to be maintained in these columns to achieve a steady state hydrodynamic condition in the system. The particles flowed from downer to riser at the bottom, and, riser to downer at the top, while pressure drops between the columns were manipulated by an auxiliary liquid stream. The auxiliary stream was responsible to mobilize solid particles at the distributor region to ensure continuous solids feed from downer to riser. When an auxiliary liquid flowrate was changed to zero, no continuous particles circulation could be formed regardless of the primary liquid flowrate because no particles from the bottom washing section could flow into the bottom of riser. With enough auxiliary liquid flow, particles at the riser distributor zone were pushed up to the entrance of the primary stream tubing and carried upwards in the riser by the combined primary and auxiliary liquid streams. Higher auxiliary liquid flowrate fed more particles to the riser thus increasing solids circulation rates. Entrained particles were then collected in the liquid-solid separator and transferred into the downer via the returning pipe. The diameter and 
liquid level within the liquid-solid separator and downer were kept equal, as well as the diameter of the solids feed and return pipes to the diameter of the riser so as to achieve a desired solids circulation rate for a given solids inventory in the downer.

\section{Hydrodynamics Regimes and Transitions}

\subsection{Hydrodynamics of the Downer}

In the downer, a counter-current flow of liquid and solids was attained as liquid moved upward and solids downward. The downer was divided vertically into three distinct zones according to the solids holdup distribution, namely a dense region (at the bottom) and a dilute region (at the upper part), also known as the freeboard region. The dilute region is required to prevent loss of particles into the raffinate. The dense region is the most vital region for adsorption in the downer as the solids holdup in this region is much higher than dilute region. Protein concentration in the dilute region is also very low. So the extent of protein adsorption in this region was assumed to be negligible. The effective bed height investigated was therefore the height of the dense phase region $H_{d}{ }^{\text {eff }}$, calculated from solids holdup in different sections of the system (Eqs.1,2).

Downer dense region operates in conventional fluidization regime, where the particles were in full suspension and uniformly distributed within this region $[5,6]$. Fig.2A shows the countercurrent contact between the two phases in the dense region. The modified Richardson and Zaki equation (Eq.3), as proposed by Kwauk [5], has been employed to compute for voidage $\varepsilon_{d}$ given in Table 2. This model is valid for conventional liquid-solid particulate fluidization, in other words, there was uniform flow structure distribution. All required correlations for evaluating the downer bed voidage are summarized in Table 2. Entrained particles from the separator then transferred into the downer through the return pipe by gravity. Assuming the solids velocity $U_{s d}$ equivalent to the particle terminal settling velocity $U_{t}$, the voidage in solids returning pipe and separator, $\varepsilon_{r e}$ and $\varepsilon_{c}$, can be estimated (Eqs.10, 11). 


\subsection{Hydrodynamics of the Riser}

The riser operates in liquid-solid circulating fluidization regime, and provides excellent interfacial mass transfer between the two phases. To maintain fast fluidization regime, the superficial liquid velocity $U_{I r}$ must exceed particle terminal velocity $U_{t}$, so that significant amount of the particles is entrained upwards to the top of the riser, and separated by a liquid-solid cylindrical separator. Co-current contact between the liquid and solid phase is shown in Fig.2B.

Existence of a lower distributor region of an extensively higher solids holdup and an upper region in the dilute-phase flow are common in fast fluidizing beds $[3,12,16]$. The solids holdup distribution describes the extent of different regions. Despite of its comparatively little height, the distributor region is of important because of the higher solids holdup distribution and thus can be assumed to obey Richardson-Zaki correlation [15]. The modified correlation (Eq.4) to calculate the voidage of the distributor region $\varepsilon_{r 1}$ is summarized in Table $2[5,11]$. A gradual transition from conventional fluidization regime in the distributor region into circulating fluidization regime in the upper dilute region has been observed $[12,16]$. This particular region is described by a uniform axial voidage profile along the riser $[10,12,16,18]$. An empirical correlation for solids holdup in the upper dilute region $\varepsilon_{s d 2}$ was proposed by Mazumder et al. [11] as a function of superficial liquid velocity and solids circulation rate (Eq.5). The use of this correlation has obtained good agreement between the predicted and experimentally obtained results reported by Lan et al. [9]. 


\section{Model Development}

The performance of the LSCFB closely depends on the hydrodynamics and how the different phases are distributed in the downer and riser. Therefore, a model that allows to describe the hydrodynamics in a flexible manner is desirable. The tanks-in-series framework allows to adjust the degree of backmixing in each of the phase independently. Additionally it allows flexibility in adjusting the residence time distribution of different phases. Therefore, it was chosen as the basis of the model.

A schematic diagram of the LSCFB system is shown in Fig.2. The mixing patterns in these columns were represented by a series of ideally mixed tanks. The tank-in-series framework was chosen because it not only allowed easy integration with the kinetics model, but also offered a straightforward comparison of the reactor performance with that of a plug flow reactor reported previously $[6,11]$. Each column in the system was divided into two series of ideally mixed stirred tanks; one corresponding to liquid phase, while the other to solid phase. Diaion HPA25 ${ }^{\circledR}$ anion exchange resins were referred to as the solid phase in the diagram. In LSCFB, entrained solid particles do not flow convectively through the downer and riser column in contrast to the liquid flows. Subsequently, the mixing in solid phase is relatively extensive than that in liquid phase. Thus, the solids phase was represented by fewer tanks than the liquid phase. In the current model, the solid phase was formed by $\mathrm{M}$ equally size ideally mixed stirred tanks, arranged in series, and each solid tank was then further subdivided into a series of $\mathrm{N}$ ideally mixed subtanks of liquid phase.

Governing equations for recovery of protein in LSCFB system were derived on basis of the research results on equilibrium isotherm and hydrodynamics of the different phases $[6,9,11]$. The following assumptions were made in the model: 
- Adsorption rate is limited by intra-particle diffusional resistance and mass transfer resistance in the laminar fluid boundary layer surrounding an individual particle.

- Surface adsorption is instantaneous and therefore a local equilibrium is established at the particle surface between protein concentrations in the two existing phases. The equilibrium behaviour of protein adsorption is well-described by the Langmuir isotherm.

- Adsorbent particles are spherical and uniform in size with a mean diameter of $d_{p}$. These particles are relatively immobile.

- Protein concentration in liquid solution of the dilute region in downer is very low, thus adsorption in these areas are negligible compared to that of the dense region.

- Particle concentration and solids holdup are uniformly distributed across the system.

- Effects of liquid phase axial dispersion and solid backmixing in each tank are negligible.

- Thermal effects are negligible, i.e. the system operates isothermally.

On the basis of these assumptions, transient model equations for the downer and riser were derived. In order to close the model equations, information on various hydrodynamic parameters were required. The framework was flexible in selecting correlations for these parameters. The correlations used in the paper are all given in Table 2.

\subsection{Formulation of the Downer}

Table 3 contains the set of equations used to model the downer. Protein mass balance in each phase was applied to develop ordinary differential equations to describe protein concentrations in liquid and solid phase (Eqs.12, 13). The effective downer height investigated was the height of dense region due to negligible protein adsorption in the dilute region. For subtank-i (Fig.3A) where $1<i<\mathrm{MN}$, the protein mass balance was derived (Eq.12A). The feed solution, with protein concentration $C_{o d}$, entered liquid subtank-1 (Fig.3B) and exited the system at $C_{e d}$ from subtank$\mathrm{MN}$ (Fig.3C). Liquid phase mass balances for subtanks 1 and $\mathrm{MN}$ are expressed by Eqs.12B, 
12C. In writing the solid phase mass balance equations for protein, the dynamic seal between the riser and downer was considered, as intermixing did not occur between the two phases in the solids feed pipe meaning no adsorption has taken place. Mass balances for the solid phase were then written so as to make the protein concentration at the outlet of downer $q_{e d}$ equivalent to that at the inlet of riser $q_{o r}$. The corresponding initial (Eq.14) and boundary (Eq.15) conditions were as described previously. Mass transfer coefficient used to model the protein adsorption in the downer was obtained from solving Eqs.16A, 16B. Protein adsorption onto the ion exchange particles obeyed the Langmuir isotherm (Eq.17). This experimental observation has been stated in literature [7].

\subsection{Formulation of the Riser}

Desorption in riser is very fast. The riser is composed of two distinct regions: distributor region, and upper dilute region. From experimentation, protein desorption rate from solid surfaces was higher in the distributor region attributed to the higher solid holdup within this region. Thus, the value of desorption rate constant in the distributor region $k_{r 1}$ differed from that of the upper dilute region $k_{\mathrm{r} 2}$, as presented in Table 5. Protein mass balances in liquid and solid phase were written (Eqs.18, 19), with initial and boundary conditions given by Eqs.20, 21.

\section{Numerical Simulation}

Fig. 3 presents the schematic diagram of LSCFB, while Table 5 summaries the parameters used in the current numerical simulation. Computational algorithm outlined in Fig. 7 is a step-by-step procedure for solving the initial value problem in coupled ordinary differential equations (ODEs) for simulating the system performance. MATLAB ${ }^{\circledR}$ code was incorporated into this model. Two model parameters specified at the outset of the simulation were, the number of tanks-in-series in each phase used to assemble the two entrained columns. The mixing behaviour in particles is considerably extensive than liquid phase, thus the former was represented by fewer tanks than 
the latter. Initially, the liquid phase superficial velocities and solid circulation rate were given, and the particle superficial velocities were calculated. Bed voidage in the downer dense region $\varepsilon_{d}$, riser distributor region $\varepsilon_{r 1}$, and upper dilute region $\varepsilon_{r 1}$ were solved (Eqs.3, 4, 5) accordingly. Effective height of the downer $H_{d}^{\text {eff }}$ was computed as a function of the solids holdup in different LSCFB sections (Eqs.10, 11), from Eqs.2, 3. At time $t=0$, the system initial conditions were set (Eqs.14, 20).

In this study, the built-in numerical solver ODE45 in MATLAB ${ }^{\circledR}$ was used to solve the system ODEs. The set of coupled ODEs (Eqs.12, 13) that integrated the liquid and solid phase mass transfer interaction in downer were solved simultaneously using the initial values of $C_{i, d}$ and $q_{j, d}$ in the tanks. The calculated protein concentration profile along the downer was assigned to $C_{i, d}$ and $q_{j, d}$. Protein concentration in the solid phase leaving at the bottom of the downer $q_{e d}$ was calculated from Eq.13B, which equivalent to that entering the riser $q_{o r}$. Next, using the value of $q_{o r}$, the coupled ODEs for the riser (Eqs.18, 19) were solved simultaneously using the same solver, to find the protein concentration profile along the riser regions. As mentioned previously, a dynamic seal is maintained between the columns. The concentration in solid particles at the top of the riser $q_{e r}$ was thus used as the new value of $q_{o d}$ as no adsorption occurred inside solids feed pipe. Subsequently, the second cycle commenced with the calculated values of $C_{e d}$ and $q_{o d}$, and the set of ODEs were solved repeatedly in the same manner. Based on this iteration, the ODE45 solver iterated over the next time step until $C_{e d}$ and $q_{o d}$ have converged.

\section{Model Validation}

Model predicted results were compared against experimental data for the liquid phase protein concentration profiles reported in the literature [6, 9], with variations in some critical operating parameters, e.g. solids circulation rate (Fig.8A), superficial liquid velocity in the downer (Fig.8B), and superficial liquid velocity in the riser (Fig.8C). Other system parameters were kept at their 
base case values, listed in Table 6 . It can be observed that both magnitude and trends of the model predictions were in reasonably good agreement with the reported data over almost all the range. One clear difference however, was that the predicted values were slightly higher than experimental data at lower end of the downer, i.e. less than $30 \%$ of $H_{d}^{\text {eff }}$. The main reason for this difference was probably due to the rapid initial particles acceleration upon entering the system, because of the fluid drag forces interaction with other particles in the entrance near to the distributors, and then more gradually further down the downer. At the same time, the flow structure developed accordingly from non-uniform distribution into a more uniform distribution. Rapid initial solids acceleration has brought to higher tendencies of solids backmixing in regions near to the liquid distributors. While this could be adapted into the current modelling framework by altering the number of tanks in the section near to the solids entrance, no special effort was made to adjust it as detailed residence time distribution profiles were not available.

\section{Results and Discussion}

With the numerical model validated, parametric sensitivity analysis of some key parameters was conducted to obtain a better understanding of mass transfer and hydrodynamics in the system. At a given inventory of solid particles, the simultaneous adsorption and desorption behaviour of protein at steady state depends primarily on: solids circulation rate $G_{s}$, superficial liquid velocity in downer $U_{l d}$, superficial liquid velocity in riser $U_{l r}$, and entering feed solution concentration $C_{o d \text {. }}$ Since many key parameters were interrelated, individual contributions of each parameter could not be uncoupled in the simulation setup. A way to uncouple and study the contribution of each parameter on the LSCFB system was through a parametric analysis where an individual effect was changed, whereas the other parameters were kept constant at base case values. In this study, the base case conditions were the experimental conditions used in model validation, as the predicted protein concentration profiles demonstrated relatively good agreement with the experimental results reported by Lan et al. $[6,9]$. This parametric study allowed ratings of the 
protein production rate (Eq.23) and overall protein recovery (Eq. 24) of the system, as defined in Table 7.

\subsection{Effects of Solids Circulation Rate}

Effects of solids circulation rate $G_{s}$ in the downer are shown in Fig.9A. For a constant total liquid flowrate, the auxiliary liquid velocity was adjusted to yield variations in $G_{s}$. As shown in Fig.9A, protein concentration in raffinate $C_{e d}$ decreases with $G_{s}$, resulted in a decreasing concentration gradient when equilibrium was attained. Table 8 verifies that the effective bed height of downer $H_{d}^{\text {eff }}$ increases with $G_{s}$, indicating an enhanced dynamic adsorption capacity, as more interfacial contact area become available. Furthermore, higher $G_{s}$ increases the liquid-solid slip velocity; thereby, high liquid-solid interfacial contact efficiency is expected for improved mass transfer coefficient $K_{L} a$ in the dense region. At the same time, the solids holdup $\varepsilon_{s d}$ decreases with $G_{s}$, as higher auxiliary liquid flowrate yields higher particle velocity, and the solid phase residence time in the downer is reduced. Therefore, a steeper concentration profile is observed at higher $G_{s}$

Fig.9B shows the anticipated protein concentration profiles in the riser at different $G_{s}$. Solid phase is denser in the distributor region and relatively diluter further down the riser. Even so, non-uniformity of solids distribution increases with $G_{s}$, resulted in a slight drop of solids holdup gradient and reduced riser desorption capacity. Characteristic of the flow structure suggested that the liquid-solid mixing along the length of the riser is more likely to be non-uniform near the distributor but developed uniformly further down the column. Referring to Table 8, increase in both protein production rate (from 37.68 to $41.54 \mathrm{~g} / \mathrm{h}$ ) and overall protein recovery (from 77.19 to $85.10 \%$ ) were achieved. It can thus be confirmed that higher $G_{s}$ is beneficial to the system performance. 


\subsection{Effects of Superficial Liquid Velocity in Downer}

Significant effects of superficial liquid velocity in the downer $U_{\| d}$ are shown in Fig.10A. Protein concentration in the raffinate $C_{e d}$ were found to increase steeply with increasing $U_{l d}$, suggesting more protein was lost at higher $U_{l d}$. This could be explained by shorter liquid phase residence time in the downer due to increasing $U_{l d}$, and hence reduced time for protein adsorption. From Table 9, it can be observed that $H_{d}{ }^{\text {eff }}$ increases with $U_{l d}$, and thereby reduced solids holdup in the downer. The mass transfer coefficient $K_{L} a$ increases slightly with $U_{l d}$. One possibility to this trend may be the increase in solid-liquid slip velocity. Despite that, the effect of mass transfer is comparatively small compared to those contributed by liquid phase residence time and solids holdup.

Since the protein loading rate and downer dense region height increase with $U_{l d}$, significantly higher amount of adsorbed protein were being carried along with the particles into the riser, as indicated by increasing $q_{e d}$. Referring to Table 9 , increase in both production rate (from 14.43 to $67.06 \mathrm{~g} / \mathrm{h}$ ) and protein recovery (from 80.13 to $82.42 \%$ ) were accomplished. It should be noted, however, that when $U_{l d}$ is too high, the total amount of protein in the liquid phase will eventually exceed the adsorption capacity of the solid particles, causing more protein lost into the raffinate.

\subsection{Effects of Superficial Liquid Velocity in Riser}

Results of the variation of both adsorption and desorption capacities of LSCFB with change in the superficial liquid velocity in the riser $U_{I r}$ are shown in Fig.11. With the solids circulation rate kept constant, it is realized that the higher the $U_{l r}$, the lesser the protein concentration in extract $C_{e r}$. Drag force exerted by the upward flowing liquid increases with $U_{I r}$, reducing the residence time available for desorption process. Consequently, the riser desorption capacity deteriorated. More particles were transferred into the downer at higher $U_{l r}$, reducing the solids holdup in riser and therefore increase in the effective height of the downer $H_{d}{ }^{\text {eff }}$. Nonetheless, increase in $H_{d}^{\text {eff }}$ 
is compensated by decrease of downer adsorption capacity due to relegation in riser desorption capacity as more protein remained in the regenerated particles. Referring to Table 10, a slight improvement can be noticed in the protein production (from 39.11 to $39.77 \mathrm{~g} / \mathrm{h}$ ) and recovery (from 80.13 to $81.47 \%$ ).

\subsection{Effects of Feed Concentration}

Effects of protein concentration in feed solution $\left(C_{o d}\right)$ were studied and the results were shown in Fig.11. When maintaining other parameters at fixed values, protein concentration in raffinate $C_{e d}$ increases with $C_{o d}$ as presented in Table 11. Higher $C_{o d}$ signifies higher protein loading rate onto the solid particles. Despite the constant solids circulation rate $G_{s}$, protein concentration in the extract $C_{\text {er }}$ increases steeply with $C_{o d}$. Referring to Table 11 , increase in both the protein production rate (from 17.01 to $59.90 \mathrm{~g} / \mathrm{h}$ ) and overall recovery (from 69.69 to $81.81 \%$ ) have been obtained with increase in $C_{o d}$.

\section{CONCLUDING REMARKS}

A general purpose, extensible, and dynamic theoretical compartmental model based upon a tanks-in-series framework incorporating the equilibrium and hydrodynamics of liquids and solid particles has been developed for continuous protein recovery in liquid-solid circulating fluidized bed (LSCFB) systems. The model was used to simulate the recovery of aqueous bovine serum albumin (BSA) solution onto Diaion HPA25 $5^{\circledR}$ particles. The model allows adjusting for the degree of backmixing in each phase for the riser and the downer, while make possible easy integration with the kinetics model and offer a straightforward comparison of the reactor performance with that of a plug flow reactor. The simulated results compare well with the experimental results obtained from the laboratory-scale BSA recovery. A systematic study of the effect of several key operating parameters was performed. The analysis revealed that both the BSA production rate and recovery increase with increasing solids circulation rate, while both of 
them decrease with increasing superficial liquid velocity in the riser. With the increase in superficial liquid velocity in the downer and feed BSA concentration, the rate of BSA production increases, but the overall recovery decreases. The computational model derived in this paper is flexible and can use different forms of ion exchange kinetics and can simulate different hydrodynamic behaviour in order to gain insight into protein recovery processes. The very nature of the model makes it a useful tool in learning other protein recovery operations for plant and animal proteins. It can also be utilized for further multi-objective optimization studies to optimize LSCFB systems. 


\section{References}

[1] A. Atta, S. A. Razzak, K. D. P. Nigam, J. X. Zhu, (Gas)-liquid-solid circulating fluidized bed reactors: characteristics and applications, Ind. Eng. Chem. Res. 48 (2009) 7876-7892.

[2] L.-S. Fan, A. Matsuura, S.-H. Chern, Hydrodynamic characteristics of a gas-liquid-solid fluidized bed containing a binary mixture of particles, AIChE J. 31 (1985) 1801-1810.

[3] R. S. B. Karri, T. M. Knowlton, A practical definition of the fast fluidization regime, in: P. Basu, M. Hario, M. Hasatani (Eds.), Circulating Fluidized Bed Technology III, Pergamon Press, Oxford, 1991, pp. 67-72.

[4] A. R. Khan, J. F. Richardson, Fluid-particle interactions and flow characteristics of fluidized beds and settling suspensions of spherical particles, Chem. Eng. Commun. 78 (1989) 111-130.

[5] M. Kwauk, Fludization: Idealized and Bubbleless, with Applications, Ellis Horwood, Ltd., Toronto, 1992, quoted in: Jin and Wei, 2006, p. 522.

[6] Q. Lan, J.-X. Zhu, A. S. Bassi, A. Margaritis, Y. Zheng, G. E. Rowe, Continuous protein recovery using a liquid-solid circulating fluidized bed ion exchange system: modeling and experimental studies, Can. J. Chem. 78 (2000) 858-866.

[7] Q. Lan, A. S. Bassi, J.-X. Zhu, A. Margaritis, A modified Langmuir model for the prediction of the effects of ionic strength on the equilibrium characteristics of protein adsorption onto ion exchange/affinity adsorbents, Chem. Eng. J. 81 (2001) 179-186.

[8] Q. Lan, A. Bassi, J.-X. Zhu, A. Margaritis, Continuous protein recovery from whey using liquid-solid circulating fluidized bed ion-exchange extraction, Biotechnol. Bioeng. 78 (2002) 157163.

[9] Q. Lan, A. S. Bassi, J.-X. Zhu, A. Margaritis, Continuous protein recovery with a liquid-solid circulating fluidized-bed ion exchanger, AIChE J. 48 (2002) 252-261.

[10] W. Liang, Z. Yu, Y. Jin, Z. Wang, Q. Wu, The phase holdups in a gas-liquid-solid circulating fluidized bed, Chem. Eng. J. Biochem. Eng. J. 58 (1995) 259-264.

[11] J. Mazumder, J. Zhu, A. S. Bassi, A. K. Ray, Modeling and simulation of liquid-solid circulating fluidized bed ion exchange system for continuous protein recovery, Biotechnol. Bioeng. 104 (2009) 111-126.

[12] E. R. Monazam, L. J. Shadle, A transient method for characterizing flow regimes in a circulating fluid bed, Powder Technol. 139 (2004) 89-97. 
[13] G. Nakhla, Zhu J.-X., Y. Cui, Liquid-solid circulating fluidized bed waste water treatment system for simultaneous carbon, nitrogen and phosphorus removal, US Patent 2004/0178132 A1, filed February 24, 2004, and issued August 28, 2007.

[14] A. Patel, J. Zhu, G. Nakhla, Simultaneous carbon, nitrogen and phosphorous removal from municipal wastewater in a circulating fluidized bed bioreactor, Chemosphere. 65 (2006) 11031112.

[15] J. F. Richardson, W. N. Zaki, Sedimentation and fluidization: part I, in: Trans. IChemE Part A, IChemE, London, 1952, pp. 35-55.

[16] Y. Zheng, J.-X. Zhu, J. Wen, S. A. Martin, A. S. Bassi, A. Margaritis, The axial hydrodynamic behavior in a liquid-solid circulating fluidized bed, Can. J. Chem. 77 (1999) 284290.

[17] Y. Zheng, J.-X. Zhu, Overall pressure balance and system stability in a liquid-solid circulating fluidized bed, Chem. Eng. J. 79 (2000) 145-153.

[18] J.-X. Zhu, D. G. Karamanev, A. S. Bassi, Y. Zheng, (Gas-)liquid-solid circulating fluidized beds and their potential applications to bioreactor engineering, Can. J. Chem. 78 (2000) 82-94. 


\section{List of Tables:}

Table 1. Specification of LSCFB system and properties of adsorbent

Table 2. Correlations for estimating LSCFB bed voidage and model parameters

Table 3. Downer design equations

Table 4. Riser design equations

Table 5. Model parameters used in numerical simulation

Table 6. Base case parameter values

Table 7. Efficiency of protein recovery in LSCFB system

Table 8. Simulation results under different $G_{s}\left(C_{o o}=2 \mathrm{~kg} / \mathrm{m}^{3}, U_{l d}=0.6 \mathrm{~m} / \mathrm{s}, U_{l r}=11.3 \mathrm{~mm} / \mathrm{s}, S=3 \mathrm{~kg}\right)$

Table 9. Simulation results under different $U_{l d}\left(C_{o d}=2 \mathrm{~kg} / \mathrm{m}^{3}, G_{s}=1.24 \mathrm{~kg} / \mathrm{m}^{2} / \mathrm{s}, U_{l r}=11.3 \mathrm{~mm} / \mathrm{s}\right.$, $S=3 \mathrm{~kg})$

Table 10. Simulation results under different $U_{l r}\left(C_{o d}=2 \mathrm{~kg} / \mathrm{m} 3, G_{s}=1.24 \mathrm{~kg} / \mathrm{m} 2 / \mathrm{s}, U_{l d}=0.60 \mathrm{~mm} / \mathrm{s}\right.$, $S=3 \mathrm{~kg})$

Table 11. Simulation results under different $C_{o d}\left(C_{o d}=2 \mathrm{~kg} / \mathrm{m} 3, G_{s}=1.24 \mathrm{~kg} / \mathrm{m} 2 / \mathrm{s}, U_{l d}=0.60 \mathrm{~mm} / \mathrm{s}\right.$, $S=3 \mathrm{~kg}$ ) 


\section{List of Figures:}

Figure 1. Schematic representation of the LSCFB system

Figure 2. Schematic representation of the tanks-in-series model in (A) the downer, and (B) the riser in the LSCFB system

Figure 3. Schematic representation of liquid-phase (A) subtank-i, (B) subtank-1, and (C) subtank-MN in the downer

Figure 4. Schematic representation of solid-phase $(A)$ tank-j, $(B)$ tank-1, and $(C)$ tank $M$ in the downer

Figure 5. Schematic representation of liquid-phase (A) subtank-i, (B) subtank-1, and (C) subtank-MN in the riser

Figure 6. Schematic representation of solid-phase $(A)$ tank-j, $(B)$ tank-1, and $(C)$ tank- $M$ in the riser

Figure 7. Algorithm for simulating the LSCFB system by tanks-in-series model

Figure 8. Experimental and predicted liquid phase protein concentration profiles under different (A) solids circulation rate $G_{s}$, (B) superficial liquid velocity in the downer $U_{l d}$, and (C) superficial liquid velocity in the riser $U_{l r}$ )

Figure 9. Liquid phase protein concentration profile in $(A)$ the downer, and $(B)$ the riser under different solids circulation rate $G_{s}\left(C_{o d}=2 \mathrm{~kg} / \mathrm{m} 3, U_{l o}=0.6 \mathrm{~mm} / \mathrm{s}, U_{l r}=11.3 \mathrm{~mm} / \mathrm{s}, S=3 \mathrm{~kg}\right)$

Figure 10. Liquid phase protein concentration profile in $(A)$ the downer, and $(B)$ the riser under different superficial liquid velocity in the downer $U_{l d}\left(C_{o c}=2 \mathrm{~kg} / \mathrm{m} 3, G_{s}=1.24 \mathrm{~kg} / \mathrm{m} 2 / \mathrm{s}\right.$, $U_{l r}=11.3 \mathrm{~mm} / \mathrm{s}, S=3 \mathrm{~kg}$ )

Figure 11. Liquid phase protein concentration profile in (A) the downer, and (B) the riser under different superficial liquid velocity in the riser $U_{l r}\left(C_{o d}=2 \mathrm{~kg} / \mathrm{m} 3, G_{s}=1.24 \mathrm{~kg} / \mathrm{m} 2 / \mathrm{s}, U_{l d}=0.60 \mathrm{~mm} / \mathrm{s}\right.$, $S=3 \mathrm{~kg})$

Figure 12. Liquid phase protein concentration profile in the downer under different feed concentration $C_{o d}\left(G_{s}=1.24 \mathrm{~kg} / \mathrm{m} 2 / \mathrm{s}, U_{l d}=0.60 \mathrm{~mm} / \mathrm{s}, U_{l r}=11.3 \mathrm{~mm} / \mathrm{s}, S=3 \mathrm{~kg}\right)$ 
Table 1. Specification of LSCFB system and properties of adsorbent

\begin{tabular}{ll|ll}
\hline & & & \\
Downer and riser (LSCFB system) & & Adsorbent particle (Diaion HPA25 ${ }^{\circledR}$ ) \\
\hline Downer bed height $H_{d}$ & $2.5 \mathrm{~m}$ & Matrix & Polystyrene (highly porous) \\
Downer bed diameter $D_{d}$ & $120 \mathrm{~mm}$ & Functional group & Quaternary alkylamine $^{-1}$ \\
Riser bed height $H_{r}$ & $3.0 \mathrm{~m}$ & lonic form & $\mathrm{Cl}^{-1}$ \\
Riser bed diameter $D_{r}$ & $38 \mathrm{~mm}$ & Average diameter $d_{p}$ & $0.32 \mathrm{~mm}$ \\
Riser distributor region height $H_{r 1}$ & $0.3 \mathrm{~m}$ & Wet density $\rho_{w}$ & $1.08 \mathrm{~g} / \mathrm{mL}$ \\
Liquid-solid separator height $H_{c}$ & $177 \mathrm{~mm}$ & Total exchange capacity $C l^{-1}$ & $0.6 \mathrm{meq} / \mathrm{mL}$ \\
Liquid-solid separator upper section diameter $D_{c}$ & $120 \mathrm{~mm}$ & Terminal velocity $U_{t}$ & $4.5 \mathrm{~mm} / \mathrm{s}$ \\
Liquid-solid separator lower section diameter $d_{c}$ & $35 \mathrm{~mm}$ & Bed expansion index $n$ & 2.67 \\
Solids return pipe length $L_{r e}$ & $500 \mathrm{~mm}$ & BSA adsorption capacity $q_{m}$ & $94.93 \mathrm{~kg} / \mathrm{m}^{3}$ \\
Solids return pipe diameter $D_{r e}$ & $35 \mathrm{~mm}$ & & \\
Solids feed pipe length $L_{f e}$ & $800 \mathrm{~mm}$ & & \\
Solids feed pipe diameter $D_{f e}$ & $35 \mathrm{~mm}$ & & \\
\hline
\end{tabular}

Table 2. Correlations for estimating LSCFB bed voidage and model parameters

\begin{tabular}{|c|c|c|c|}
\hline Downer effective bed height $H_{d}^{\text {eff }}$ & $\mathrm{H}_{\mathrm{d}}^{\text {eff }} \varepsilon_{\mathrm{sd}} \mathrm{A}_{\mathrm{d}}=S / \rho_{\mathrm{a}}-\mathrm{A}_{\mathrm{r}}\left(\mathrm{h}_{\mathrm{r} 1} \varepsilon_{\mathrm{sr} 1}+\mathrm{h}_{\mathrm{r} 2} \varepsilon_{\mathrm{sr} 2}\right)-\mathrm{V}_{\mathrm{p}}\left(1-\varepsilon_{\mathrm{p}}\right)$ & {$[8,16]$} & (Eq.1) \\
\hline Solid volume in sections $V_{p}\left(1-\varepsilon_{p}\right)$ & $V_{p}\left(1-\varepsilon_{p}\right)=4 / 3 h_{c} \varepsilon_{s c} A_{c}-L_{r e} A_{r e}\left(1-\varepsilon_{r e}\right)-L_{f e} A_{f e}\left(1-\varepsilon_{f e}\right)$ & {$[8,16]$} & (Eq.2) \\
\hline Downer dense region voidage $\varepsilon_{d}$ & $U_{l d}+U_{s d} \varepsilon_{d} /\left(1-\varepsilon_{d}\right)=U_{i} \varepsilon_{d}^{n}$ & {$[3,9]$} & (Eq.3) \\
\hline Riser distributor region voidage $\varepsilon_{r 1}$ & $U_{\mathrm{lr}}-U_{s r} \varepsilon_{r 1} /\left(1-\varepsilon_{r 1}\right)=U_{l} \varepsilon_{r 1}{ }^{n}$ & {$[8,9]$} & (Eq.4) \\
\hline Riser top dilute region solids holdup $\varepsilon_{s r 2}$ & $\varepsilon_{\mathrm{sr} 2}=2.64 \times 10^{-14} \mathrm{U}_{\mathrm{lr}}^{-5.343}+2.57 \times 10^{-5} \mathrm{G}_{\mathrm{s}} \mathrm{U}_{\mathrm{lr}}^{-1.5 / 8}$ & [8] & (Eq.5) \\
\hline Bed expansion index $n$ & $\mathrm{n}=\operatorname{Re}_{\mathrm{t}}^{-0.01}\left(4.4+18 \mathrm{~d}_{\mathrm{p}} / \mathrm{D}_{\mathrm{c}}\right) \quad$ for $1<\operatorname{Re}_{\mathrm{t}}<200$ & {$[9,13]$} & (Eq.6) \\
\hline Terminal Reynolds $R e_{t}$ & $R e_{t}=U_{t} d_{p} \rho / \mu$ & [17] & (Eq.7) \\
\hline Terminal velocity $U_{t}$ & $U_{t}=g_{p}^{2}\left(\rho_{w}-\rho\right) / 18 \mu$ & [17] & (Eq.8) \\
\hline Superficial liquid velocity at $(\varepsilon=1) U_{i}$ & $\mathrm{U}_{\mathrm{i}} / \mathrm{U}_{\mathrm{t}}=1-1.15\left(\mathrm{~d}_{\mathrm{p}} / \mathrm{D}_{\mathrm{c}}\right)^{0.6}$ & [18] & (Eq.9) \\
\hline Separator voidage $\varepsilon_{c}$ & $1-\varepsilon_{c}=\left(D_{r} / D_{c}\right)^{2} G_{s} / \rho_{s} U_{t}$ & {$[16]$} & (Eq.10) \\
\hline Return pipe voidage $\varepsilon_{r e}$ & $1-\varepsilon_{\mathrm{re}}=\left(D_{\mathrm{r}} / D_{\mathrm{re}}\right)^{2} \mathrm{G}_{\mathrm{s}} / \rho_{\mathrm{s}} \mathrm{U}_{\mathrm{t}}$ & {$[16]$} & (Eq.11) \\
\hline
\end{tabular}




\begin{tabular}{|c|c|c|c|}
\hline \multicolumn{4}{|l|}{ Liquid phase mass balance equations } \\
\hline $\mathrm{dC}_{\mathrm{i}, \mathrm{d}} / \mathrm{dt}=\mathrm{U}_{\mathrm{Id}}\left(\mathrm{C}_{\mathrm{i}-1, \mathrm{~d}}-\mathrm{C}_{\mathrm{i}, \mathrm{d}}\right) / \mathrm{h}_{\mathrm{ld}} \varepsilon_{\mathrm{d}}-\mathrm{K}_{\mathrm{L}} \mathrm{a}\left(1-\varepsilon_{\mathrm{d}}\right)\left(\mathrm{C}_{\mathrm{i}, \mathrm{d}}-\mathrm{C}_{\mathrm{eq}}\right) / \varepsilon_{\mathrm{d}}$ & & for $1<\mathrm{i}<\mathrm{MN}$ & $(\mathrm{Eq} .12 \mathrm{~A})$ \\
\hline $\mathrm{dC}_{1, \mathrm{~d}} / \mathrm{dt}=\mathrm{U}_{\mathrm{ld}}\left(\mathrm{C}_{1, \mathrm{~d} \_ \text {in }}-\mathrm{C}_{1, \mathrm{~d}}\right) / \mathrm{h}_{\mathrm{dd}} \varepsilon_{\mathrm{d}}-\mathrm{K}_{\mathrm{L}} \mathrm{a}\left(1-\varepsilon_{\mathrm{d}}\right)\left(\mathrm{C}_{1, \mathrm{~d}}-\mathrm{C}_{\mathrm{eq}}\right) / \varepsilon_{\mathrm{d}}$ & & for $i=1$ & (Eq.12B) \\
\hline $\mathrm{dC}_{\mathrm{MN}, \mathrm{d}} / \mathrm{dt}=\mathrm{U}_{\mathrm{ld}}\left(\mathrm{C}_{\mathrm{MN}-1, \mathrm{~d}}-\mathrm{C}_{\mathrm{MN}, \mathrm{d}}\right) / \mathrm{h}_{\mathrm{ld}} \varepsilon_{\mathrm{d}}-\mathrm{K}_{\mathrm{L}} \mathrm{a}\left(1-\varepsilon_{\mathrm{d}}\right)\left(\mathrm{C}_{\mathrm{MN}, \mathrm{d}}-\mathrm{C}_{\mathrm{eq}}\right) / \varepsilon_{\mathrm{d}}$ & & for $\mathrm{i}=\mathrm{MN}$ & (Eq.12C) \\
\hline \multicolumn{4}{|l|}{ Solid phase mass balance equations } \\
\hline $\mathrm{dq}_{\mathrm{i}, \mathrm{d}} / \mathrm{dt}=\mathrm{U}_{\mathrm{sd}}\left(\mathrm{q}_{\mathrm{i}+1, \mathrm{~d}}-\mathrm{q}_{\mathrm{i}, \mathrm{d}}\right) / \mathrm{h}_{\mathrm{sd}}\left(1-\varepsilon_{\mathrm{d}}\right)+\sum_{\mathrm{i}} \mathrm{K}_{\mathrm{L}} \mathrm{a}\left(1-\varepsilon_{\mathrm{d}}\right)\left(\mathrm{C}_{\mathrm{i}, \mathrm{d}}-\mathrm{C}_{e q}\right) / \varepsilon_{\mathrm{d}}$ & $i=(j-1) N+1,(j-1) N+2, \ldots,(j-1) N+N$ & for $1<j<M$ & (Eq.13A) \\
\hline $\mathrm{dq}_{1, \mathrm{~d}} / \mathrm{dt}=\mathrm{U}_{\mathrm{sd}}\left(\mathrm{q}_{2, \mathrm{~d}}-\mathrm{q}_{1, \mathrm{~d}}\right) / \mathrm{h}_{\mathrm{sd}}\left(1-\varepsilon_{\mathrm{d}}\right)+\sum_{\mathrm{i}} \mathrm{K}_{\mathrm{L}} \mathrm{a}\left(1-\varepsilon_{\mathrm{d}}\right)\left(\mathrm{C}_{\mathrm{i}, \mathrm{d}}-\mathrm{C}_{\mathrm{eq}}\right) / \varepsilon_{\mathrm{d}}$ & $i=1,2, \ldots, N$ & for $j=1$ & (Eq.13B) \\
\hline $\mathrm{dq}_{\mathrm{M}, \mathrm{d}} / \mathrm{dt}=\mathrm{U}_{\mathrm{sd}}\left(\mathrm{q}_{\mathrm{M}, \mathrm{d} \text { in }}-\mathrm{q}_{\mathrm{M}, \mathrm{d}}\right) / \mathrm{h}_{\mathrm{sd}}\left(1-\varepsilon_{\mathrm{d}}\right)+\sum_{\mathrm{i}} \mathrm{K}_{\mathrm{L}} \mathrm{a}\left(1-\varepsilon_{\mathrm{d}}\right)\left(\mathrm{C}_{\mathrm{i}, \mathrm{d}}-\mathrm{C}_{e q}\right) / \varepsilon_{\mathrm{d}}$ & $\mathrm{i}=(\mathrm{M}-1) \mathrm{N}+1,(\mathrm{M}-1) \mathrm{N}+2, \ldots, \mathrm{MN}$ & for $j=M$ & (Eq.13C) \\
\hline \multicolumn{4}{|l|}{ Initial conditions } \\
\hline $\mathrm{C}_{\mathrm{i}, \mathrm{d}}(\mathrm{t}=0)=0$ & & for $1 \leq \mathrm{i} \leq \mathrm{MN}$ & (Eq.14A) \\
\hline $\mathrm{q}_{\mathrm{j}, \mathrm{d}}(\mathrm{t}=0)=0$ & & for $1 \leq \mathrm{j} \leq \mathrm{M}$ & (Eq.14B) \\
\hline \multicolumn{4}{|l|}{ Boundary conditions } \\
\hline $\mathrm{C}_{\mathrm{i}, \mathrm{d} \_ \text {in }}=\mathrm{C}_{\mathrm{od}}$ & & for $i=1$ & (Eq.15A) \\
\hline $\mathrm{C}_{\mathrm{i}, \mathrm{d}}=\mathrm{C}_{\mathrm{ed}}$ & & for $\mathrm{i}=\mathrm{MN}$ & (Eq.15B) \\
\hline$q_{m, d}=q_{e d}=q_{o r}$ & & for $j=1$ & (Eq.15C) \\
\hline$q_{m, d \_i n}=q_{o d}=q_{e r}$ & & for $j=M$ & (Eq.15D) \\
\hline \multicolumn{4}{|l|}{ Lumped mass transfer coefficient } \\
\hline $\mathrm{k}_{\mathrm{f}}=\mathrm{D}_{\mathrm{m}}\left[2+1.03\left(\varepsilon_{\mathrm{sd}} R_{\mathrm{p}}\right)^{0.5}(\mathrm{Sc})^{0.33}\right] / \mathrm{d}_{\mathrm{p}}$ & & & (Eq.16A) \\
\hline $\mathrm{K}_{\mathrm{L}}=\Psi \mathrm{k}_{\mathrm{f}}$ & & & (Eq.16B) \\
\hline \multicolumn{4}{|l|}{ Langmuir isotherm } \\
\hline$C_{e q}=K_{d} q_{d} /\left(q_{m}-q_{d}\right)$ & & & (Eq.17) \\
\hline
\end{tabular}




\section{Liquid phase mass balance equations}

$\mathrm{dC}_{\mathrm{i}, \mathrm{r}} / \mathrm{dt}=\mathrm{U}_{\mathrm{lr}}\left(\mathrm{C}_{\mathrm{i}-1, \mathrm{r}}-\mathrm{C}_{\mathrm{i}, \mathrm{r}}\right) / \mathrm{h}_{\mathrm{rr}} \varepsilon_{\mathrm{r}}+\mathrm{k}_{\mathrm{r}} \mathrm{q}_{\mathrm{j}, \mathrm{r}}\left(1-\varepsilon_{\mathrm{r}}\right) / \varepsilon_{\mathrm{r}}$

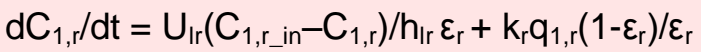

$\mathrm{dC}_{\mathrm{MN}, \mathrm{r}} / \mathrm{dt}=\mathrm{U}_{\mathrm{Ir}}\left(\mathrm{C}_{\mathrm{MN}-1, \mathrm{r}}-\mathrm{C}_{\mathrm{MN}, \mathrm{r}}\right) / \mathrm{h}_{\mathrm{Ir}} \varepsilon_{\mathrm{r}}+\mathrm{k}_{\mathrm{r}} \mathrm{q}_{\mathrm{M}, \mathrm{r}}\left(1-\varepsilon_{\mathrm{r}}\right) / \varepsilon_{\mathrm{r}}$

Solid phase mass balance equations

$$
\begin{aligned}
& d q_{i, r} / d t=U_{s d}\left(q_{j-1, r}-q_{i, r}\right) / h_{s r}\left(1-\varepsilon_{r}\right)-\sum_{i} k_{r} q_{i, r}\left(1-\varepsilon_{r}\right) / \varepsilon_{r} \\
& d q_{1, r} / d t=U_{s d}\left(q_{1, r \_i n}-q_{1, r}\right) / h_{s r}\left(1-\varepsilon_{r}\right)-\sum_{i} k_{r} q_{1, r}\left(1-\varepsilon_{r}\right) / \varepsilon_{r} \\
& d q_{M, r} / d t=U_{s d}\left(q_{M-1, r}-q_{M, r}\right) / h_{s r}\left(1-\varepsilon_{r}\right)-\sum_{i} k_{r} q_{M, r}\left(1-\varepsilon_{r}\right) / \varepsilon_{r}
\end{aligned}
$$

Initial conditions

$\mathrm{C}_{\mathrm{i}, \mathrm{r}}(\mathrm{t}=0)=0$

$\mathrm{q}_{\mathrm{j}, \mathrm{r}}(\mathrm{t}=0)=0$

\section{Boundary conditions}

$\mathrm{C}_{\mathrm{i}, \mathrm{r} \text { in }}=\mathrm{C}_{\mathrm{or}}=0$

$\mathrm{C}_{\mathrm{i}, \mathrm{r}}=\mathrm{C}_{\mathrm{er}}$

$q_{m, r_{i} \text { in }}=q_{o r}=q_{e d}$

$q_{m, r}=q_{e r}=q_{o d}$

Desorption rate coefficient

$$
\mathrm{k}_{\mathrm{r}}=\mathrm{k}_{\mathrm{r} 1}
$$

$\mathrm{k}_{\mathrm{r}}=\mathrm{k}_{\mathrm{r} 2}$

\section{for $1<i<M N$}

for $\mathrm{i}=1$

for $\mathrm{i}=\mathrm{MN}$

(Eq.18A)

(Eq.18C)

$i=(j-1) N+1,(j-1) N+2, \ldots,(j-1) N+N$

for $1<j<M$

(Eq.19A)

$\mathrm{i}=1,2, \ldots, \mathrm{N}$

for $j=1$

$\mathrm{i}=(\mathrm{M}-1) \mathrm{N}+1,(\mathrm{M}-1) \mathrm{N}+2, \ldots, \mathrm{MN}$

for $j=M$

(Eq.19B)

(Eq.19C)

for $1 \leq \mathrm{i} \leq \mathrm{MN}$

(Eq.20A)

for $1 \leq \mathrm{j} \leq \mathrm{M}$

(Eq.20B)

for $\mathrm{i}=1$

for $\mathrm{i}=\mathrm{MN}$

for $j=1$

for $\mathrm{j}=\mathrm{M}$

(Eq.21A)

(Eq.21B)

(Eq.21C)

(Eq.21D)

for $M \leq\left(H_{r 1} / h_{s d}\right)$

(Eq.22A)

for $M>\left(H_{r 1} / h_{s d}\right)$ 
Table 5. Model parameters used in numerical simulation

\begin{tabular}{ll} 
Model parameter & Calibrated value \\
\hline Constant factor defined in $(\mathrm{Eq} .16 \mathrm{~b}) \Psi$ & $0.003944 \exp \left(3.9336 \mathrm{G}_{\mathrm{s}}\right)$ \\
Dissociation constant $K_{d}\left(\mathrm{~kg} / \mathrm{m}^{3}\right)$ & 0.25 \\
Desorption rate constant of distributor region $k_{r 1}(\mathrm{~m} / \mathrm{s})$ & 0.005253 \\
Desorption rate constant of upper dilute region $k_{\mathrm{r} 2}(\mathrm{~m} / \mathrm{s})$ & 0.0006 \\
\hline
\end{tabular}

Table 6. Base case parameter values

\begin{tabular}{ll}
\hline Operating parameter & Value \\
\hline Feed concentration $C_{o d}\left(\mathrm{~kg} / \mathrm{m}^{3}\right)$ & 2 \\
Solids circulation rate $G_{s}\left(\mathrm{~kg} / \mathrm{m}^{2} / \mathrm{s}\right)$ & 1.24 \\
Downer superficial liquid velocity $U_{l d}(\mathrm{~m} / \mathrm{s})$ & 0.0006 \\
Riser superficial liquid velocity $U_{l r}(\mathrm{~m} / \mathrm{s})$ & 0.0113 \\
Amount of dry solid particles $S(\mathrm{~kg})$ & 3 \\
\hline
\end{tabular}

Table 7. Efficiency of protein recovery in LSCFB system

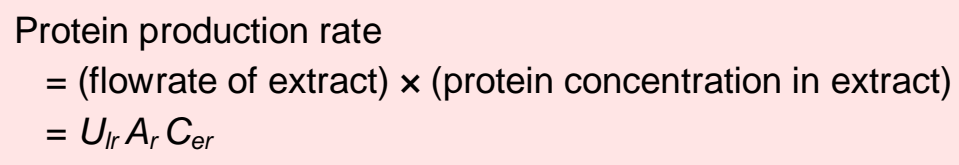

Overall protein recovery

$=($ protein amount in extract) $/$ (protein amount in feed)

$=U_{l r} A_{r} C_{e r} /\left(U_{l d} A_{d} C_{o d}\right)$ 
Table 8. Simulation results under different $G_{s}\left(C_{o d}=2 \mathrm{~kg} / \mathrm{m}^{3}, U_{l d}=0.6 \mathrm{~m} / \mathrm{s}, U_{l r}=11.3 \mathrm{~mm} / \mathrm{s}, S=3 \mathrm{~kg}\right)$

\begin{tabular}{ccccccccccccc}
\hline $\begin{array}{c}\mathrm{G}_{\mathrm{s}} \\
\left(\mathrm{kg} / \mathrm{m}^{2} / \mathrm{s}\right)\end{array}$ & $\varepsilon_{\mathrm{sd}}$ & $\varepsilon_{\mathrm{sr} 1}$ & $\varepsilon_{\mathrm{sr} 2}$ & $\mathrm{H}_{\mathrm{d}}{ }^{\text {eff }}(\mathrm{m})$ & $\begin{array}{c}10^{11} \mathrm{D}_{\mathrm{m}} \\
\left(\mathrm{m}^{2} / \mathrm{s}\right)\end{array}$ & $\begin{array}{c}10^{3} \mathrm{~K}_{\mathrm{L}} \\
\left(\mathrm{s}^{-1}\right)\end{array}$ & $\begin{array}{c}\mathrm{C}_{\text {ed }} \\
\left(\mathrm{kg} / \mathrm{m}^{3}\right)\end{array}$ & $\begin{array}{c}\mathrm{C}_{\text {er }} \\
\left(\mathrm{kg} / \mathrm{m}^{3}\right)\end{array}$ & $\begin{array}{c}\mathrm{q}_{\text {ed }} \\
\left(\mathrm{kg} / \mathrm{m}^{3}\right)\end{array}$ & $\begin{array}{c}\mathrm{q}_{\mathrm{er}} \\
\left(\mathrm{kg} / \mathrm{m}^{3}\right)\end{array}$ & $P(\mathrm{~g} / \mathrm{h})$ & $\mathrm{R}(\%)$ \\
\hline 1.06 & 0.324 & 0.1026 & 0.0328 & 0.7683 & 6.13 & 3.70 & 0.5379 & 0.8197 & 49.93 & 27.39 & 37.68 & 77.19 \\
1.24 & 0.316 & 0.1158 & 0.0383 & 0.7942 & 6.13 & 7.50 & 0.2050 & 0.8509 & 44.79 & 25.21 & 39.11 & 80.13 \\
1.42 & 0.308 & 0.1284 & 0.0438 & 0.8225 & 6.13 & 15.1 & 0.0962 & 0.9037 & 41.53 & 24.03 & 41.54 & 85.10 \\
\hline
\end{tabular}

Table 9. Simulation results under different $U_{l d}\left(C_{o d}=2 \mathrm{~kg} / \mathrm{m}^{3}, G_{s}=1.24 \mathrm{~kg} / \mathrm{m}^{2} / \mathrm{s}, U_{l r}=11.3 \mathrm{~mm} / \mathrm{s}, S=3 \mathrm{~kg}\right)$

\begin{tabular}{ccccccccccccc}
\hline $\begin{array}{c}\mathrm{U}_{\mathrm{ld}} \\
(\mathrm{mm} / \mathrm{s})\end{array}$ & $\varepsilon_{\mathrm{sd}}$ & $\varepsilon_{\mathrm{sr} 1}$ & $\varepsilon_{\mathrm{sr} 2}$ & $\mathrm{H}_{\mathrm{d}}{ }^{\text {eff }}(\mathrm{m})$ & $\begin{array}{c}10^{11} \mathrm{D}_{\mathrm{m}} \\
\left(\mathrm{m}^{2} / \mathrm{s}\right)\end{array}$ & $\begin{array}{c}10^{3} \mathrm{~K}_{\mathrm{L}} \mathrm{a} \\
\left(\mathrm{s}^{-1}\right)\end{array}$ & $\begin{array}{c}\mathrm{C}_{\text {ed }} \\
\left(\mathrm{kg} / \mathrm{m}^{3}\right)\end{array}$ & $\begin{array}{c}\mathrm{C}_{\text {er }} \\
\left(\mathrm{kg} / \mathrm{m}^{3}\right)\end{array}$ & $\begin{array}{c}\mathrm{q}_{\text {ed }} \\
\left(\mathrm{kg} / \mathrm{m}^{3}\right)\end{array}$ & $\begin{array}{c}\mathrm{q}_{\mathrm{er}} \\
\left(\mathrm{kg} / \mathrm{m}^{3}\right)\end{array}$ & $\mathrm{P}(\mathrm{g} / \mathrm{h})$ & $\mathrm{R}(\%)$ \\
\hline 0.60 & 0.316 & 0.1158 & 0.0383 & 0.7942 & 6.13 & 14.5 & 0.2050 & 0.8509 & 44.79 & 25.21 & 39.11 & 80.13 \\
0.80 & 0.274 & 0.1158 & 0.0383 & 0.9151 & 6.13 & 14.9 & 0.3600 & 1.1649 & 61.14 & 34.46 & 53.55 & 82.27 \\
1.00 & 0.239 & 0.1158 & 0.0383 & 1.0523 & 6.13 & 15.2 & 0.5824 & 1.4588 & 76.05 & 43.00 & 67.06 & 82.42 \\
\hline
\end{tabular}

Table 10. Simulation results under different $U_{l r}\left(C_{o o}=2 \mathrm{~kg} / \mathrm{m} 3, G_{s}=1.24 \mathrm{~kg} / \mathrm{m} 2 / \mathrm{s}, U_{l d}=0.60 \mathrm{~mm} / \mathrm{s}, S=3 \mathrm{~kg}\right)$

\begin{tabular}{|c|c|c|c|c|c|c|c|c|c|c|c|c|}
\hline $\begin{array}{c}U_{\mathrm{lr}} \\
(\mathrm{mm} / \mathrm{s})\end{array}$ & $\varepsilon_{\mathrm{sd}}$ & $\varepsilon_{\text {sr1 }}$ & $\varepsilon_{\mathrm{sr} 2}$ & $\mathrm{H}_{\mathrm{d}}^{\mathrm{eff}}(\mathrm{m})$ & $\begin{array}{c}10^{11} D_{m} \\
\left(m^{2} / s\right)\end{array}$ & $\begin{array}{c}10^{3} \mathrm{~K}_{\mathrm{L}} \mathrm{a} \\
\left(\mathrm{s}^{-1}\right)\end{array}$ & $\begin{array}{c}\mathrm{C}_{\mathrm{ed}} \\
\left(\mathrm{kg} / \mathrm{m}^{3}\right)\end{array}$ & $\begin{array}{c}\mathrm{C}_{\mathrm{er}} \\
\left(\mathrm{kg} / \mathrm{m}^{3}\right)\end{array}$ & $\begin{array}{c}\mathrm{q}_{\mathrm{ed}} \\
\left(\mathrm{kg} / \mathrm{m}^{3}\right)\end{array}$ & $\begin{array}{c}\mathrm{q}_{\mathrm{er}} \\
\left(\mathrm{kg} / \mathrm{m}^{3}\right)\end{array}$ & $P(g / h)$ & $\mathrm{R}(\%)$ \\
\hline 11.3 & 0.316 & 0.1158 & 0.0383 & 0.7942 & 6.13 & 14.5 & 0.2050 & 0.8509 & 44.79 & 25.21 & 39.11 & 80.13 \\
\hline 14.9 & 0.316 & 0.0875 & 0.0245 & 0.8088 & 6.13 & 14.5 & 0.2615 & 0.6466 & 54.70 & 35.79 & 39.19 & 80.28 \\
\hline 18.7 & 0.316 & 0.0690 & 0.0170 & 0.8169 & 6.13 & 14.5 & 0.3723 & 0.5228 & 66.60 & 48.00 & 39.77 & 81.47 \\
\hline
\end{tabular}

Table 11. Simulation results under different $C_{o d}\left(C_{o d}=2 \mathrm{~kg} / \mathrm{m} 3, G_{s}=1.24 \mathrm{~kg} / \mathrm{m} 2 / \mathrm{s}, U_{l d}=0.60 \mathrm{~mm} / \mathrm{s}, S=3 \mathrm{~kg}\right)$

\begin{tabular}{ccccccccccc}
\hline $\begin{array}{c}\mathrm{C}_{\text {od }} \\
\left(\mathrm{kg} / \mathrm{m}^{3}\right)\end{array}$ & $\rho\left(\mathrm{kg} / \mathrm{m}^{3}\right)$ & $\mu(\mathrm{kg} / \mathrm{m} / \mathrm{s})$ & $\begin{array}{c}10^{11} \mathrm{D}_{\mathrm{m}} \\
\left(\mathrm{m}^{2} / \mathrm{s}\right)\end{array}$ & $\begin{array}{c}10^{3} \mathrm{~K}_{\mathrm{L}} \mathrm{a} \\
\left(\mathrm{s}^{-1}\right)\end{array}$ & $\begin{array}{c}\mathrm{C}_{\text {ed }} \\
\left(\mathrm{kg} / \mathrm{m}^{3}\right)\end{array}$ & $\begin{array}{c}\mathrm{C}_{\text {er }} \\
\left(\mathrm{kg} / \mathrm{m}^{3}\right)\end{array}$ & $\begin{array}{c}\mathrm{q}_{\text {ed }} \\
\left(\mathrm{kg} / \mathrm{m}^{3}\right)\end{array}$ & $\begin{array}{c}\mathrm{q}_{\mathrm{er}} \\
\left(\mathrm{kg} / \mathrm{m}^{3}\right)\end{array}$ & $\begin{array}{c}P(\mathrm{~g} / \mathrm{h}) \\
\mathrm{R}(\%)\end{array}$ \\
\hline 1.00 & 999.6 & 0.9471 & 6.13 & 14.5 & 0.0871 & 0.3700 & 19.74 & 11.04 & 17.01 & 69.69 \\
2.00 & 999.2 & 0.9526 & 6.13 & 14.5 & 0.2050 & 0.8509 & 44.79 & 25.21 & 39.11 & 80.13 \\
3.00 & 998.8 & 0.9582 & 6.13 & 14.5 & 0.3597 & 1.3031 & 68.35 & 38.54 & 59.90 & 81.81 \\
\hline
\end{tabular}




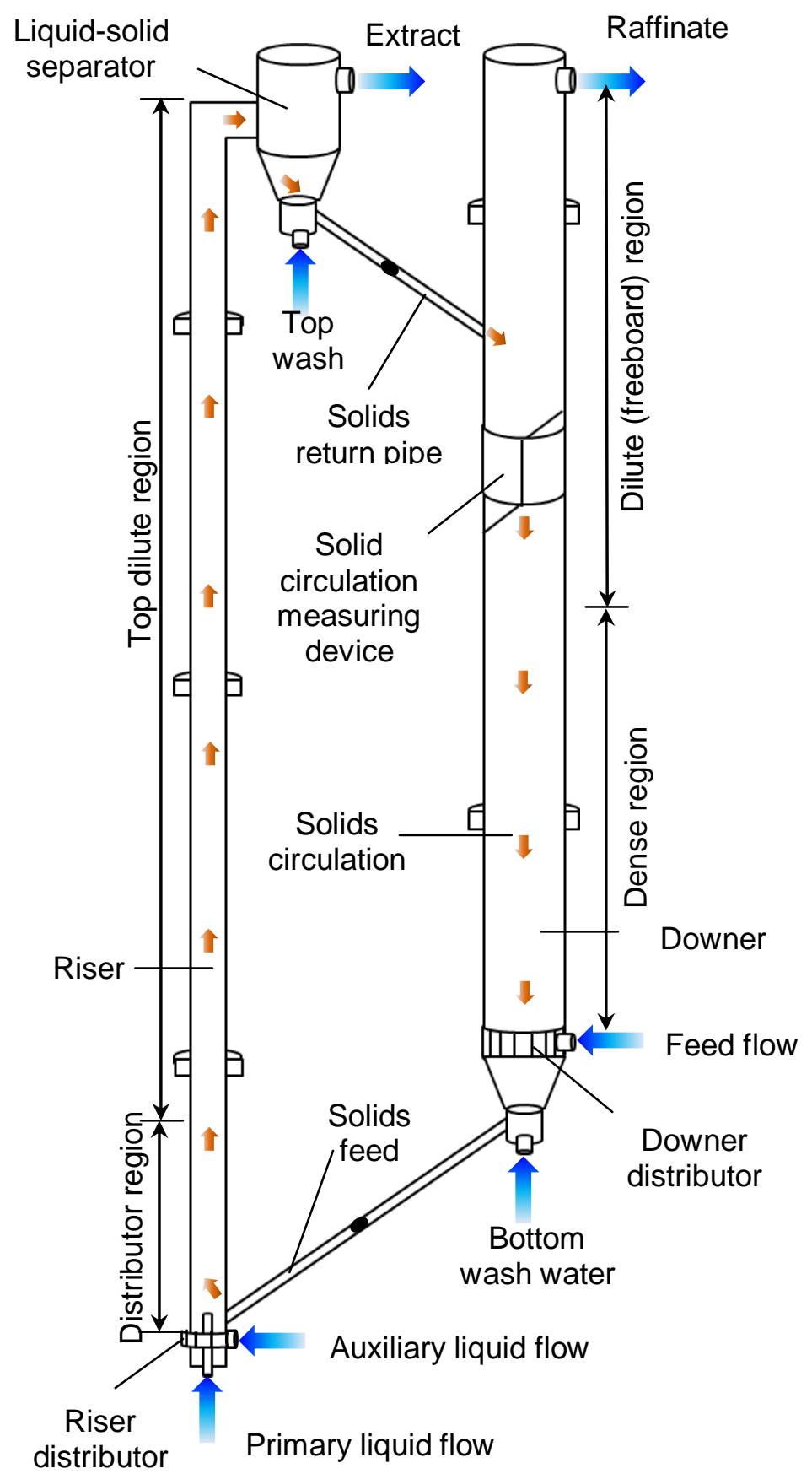

Figure 1. Schematic representation of the LSCFB system 
(B)
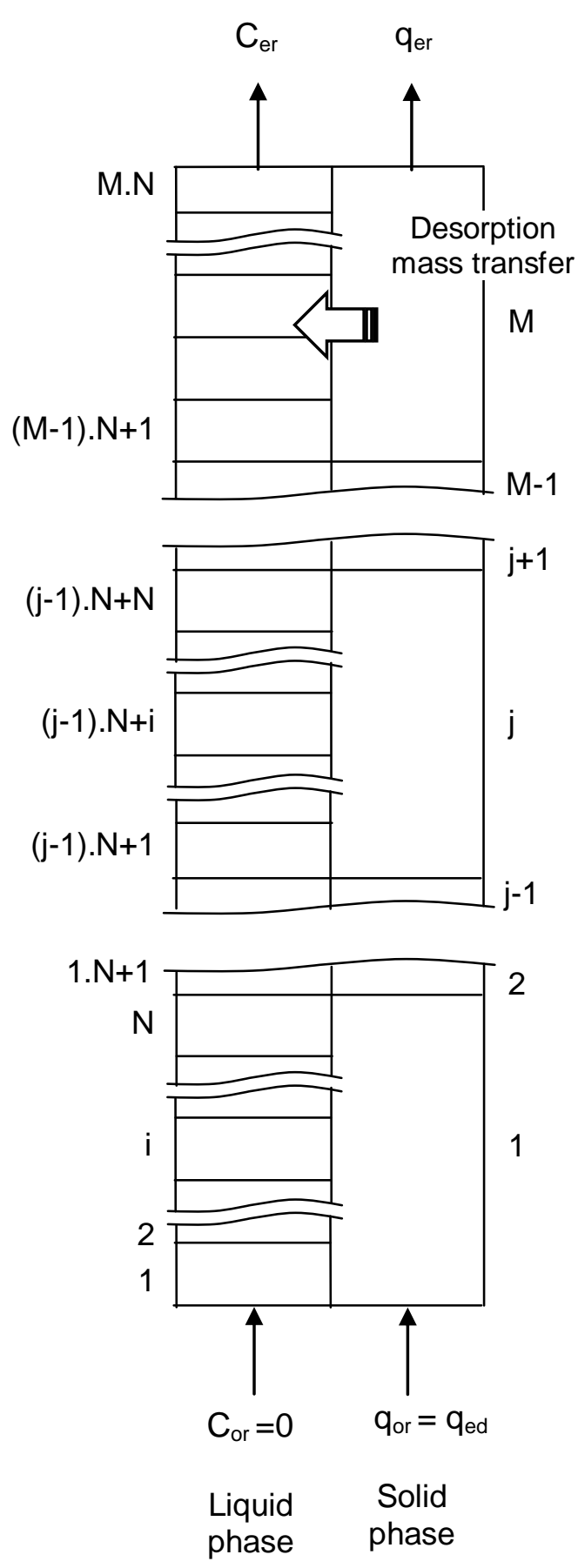

(A)
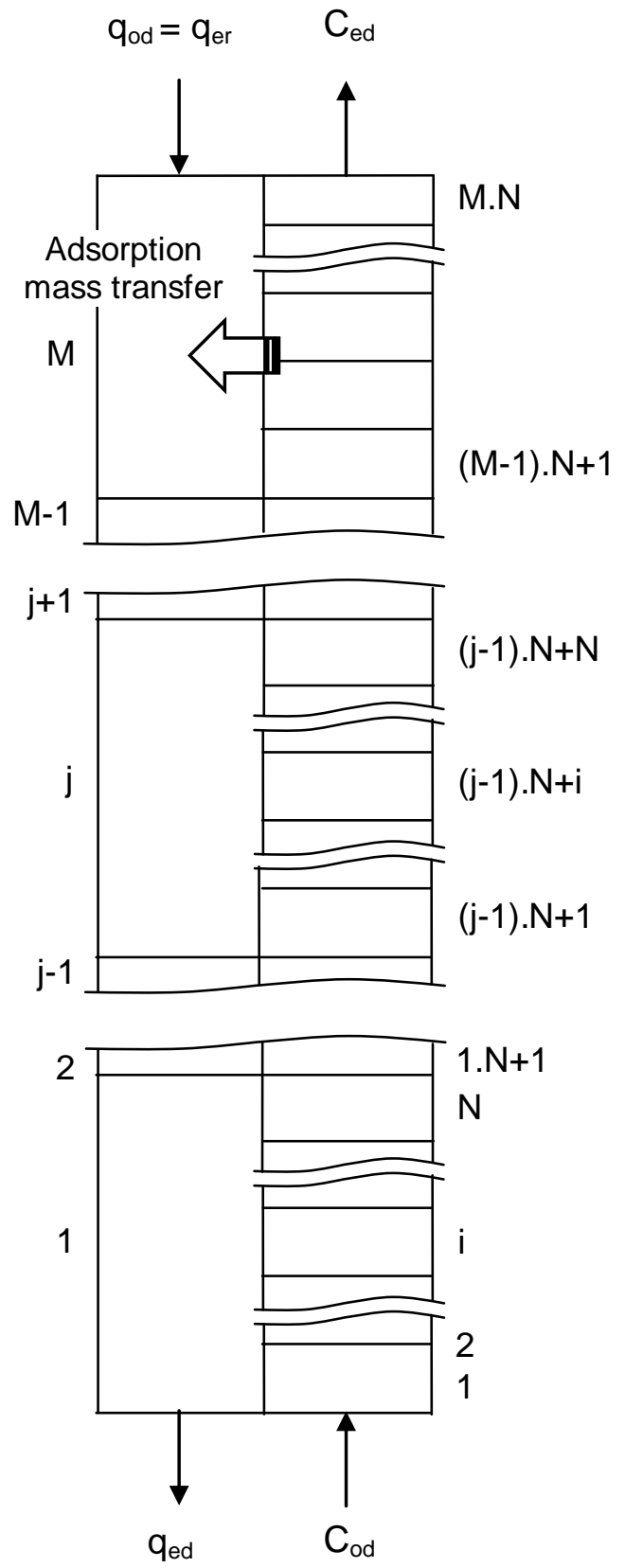

Solid Liquid phase phase

Figure 2. Schematic representation of the tanks-in-series model in (A) the downer, and $(B)$ the riser in the LSCFB system 
(A)

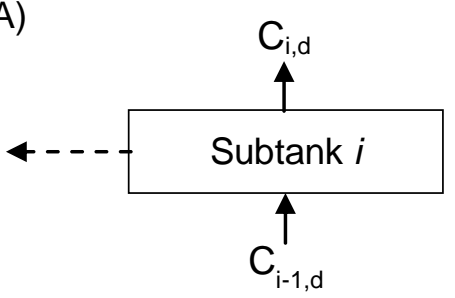

(B)

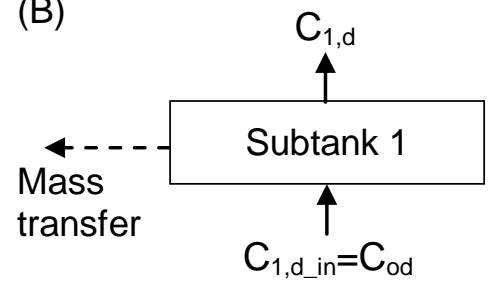

(C)

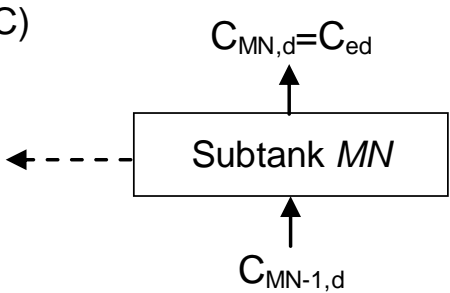

Figure 3. Schematic representation of liquid-phase (A) subtank-i, (B) subtank-1, and (C) subtank-MN in the downer

(A)

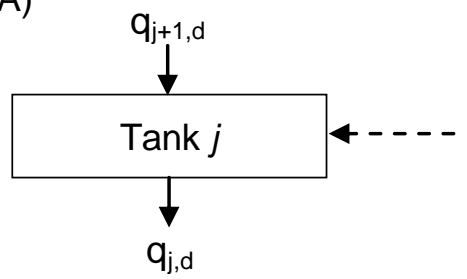

(B)

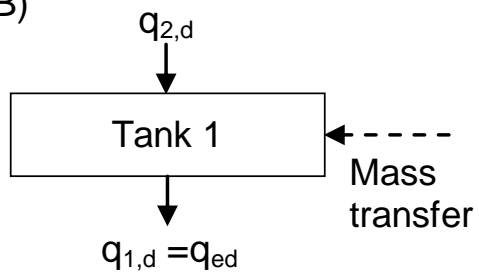

(C)

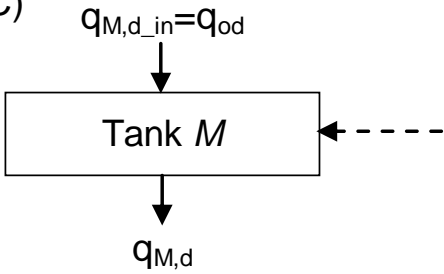

Figure 4. Schematic representation of solid-phase (A) tank-j, (B) tank-1, and (C) tank $M$ in the downer

(A)

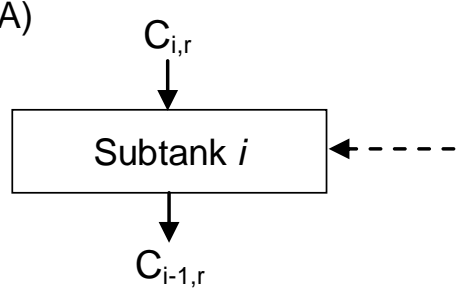

(B)

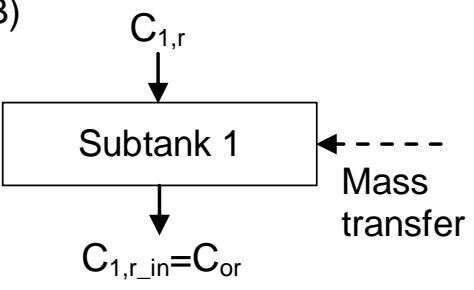

(C)
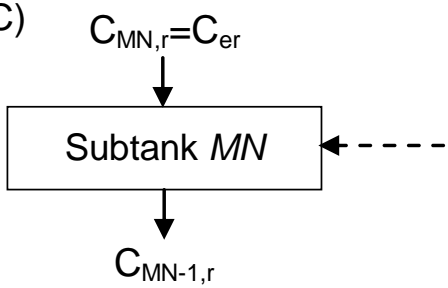

Figure 5. Schematic representation of liquid-phase (A) subtank-i, (B) subtank-1, and (C) subtank- $M N$ in the riser

(A)

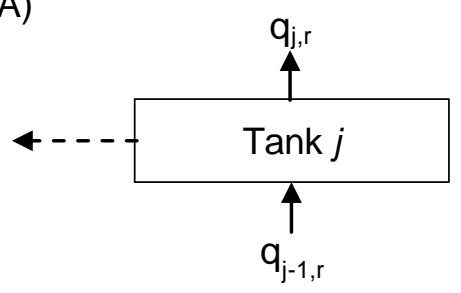

(B)

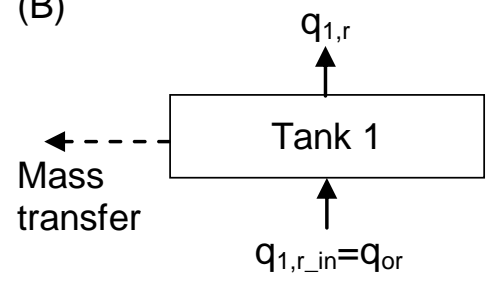

(C)

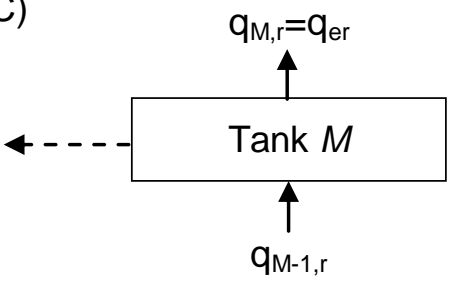

Figure 6. Schematic representation of solid-phase (A) tank-j, $(B)$ tank-1, and $(C)$ tank- $M$ in the riser 


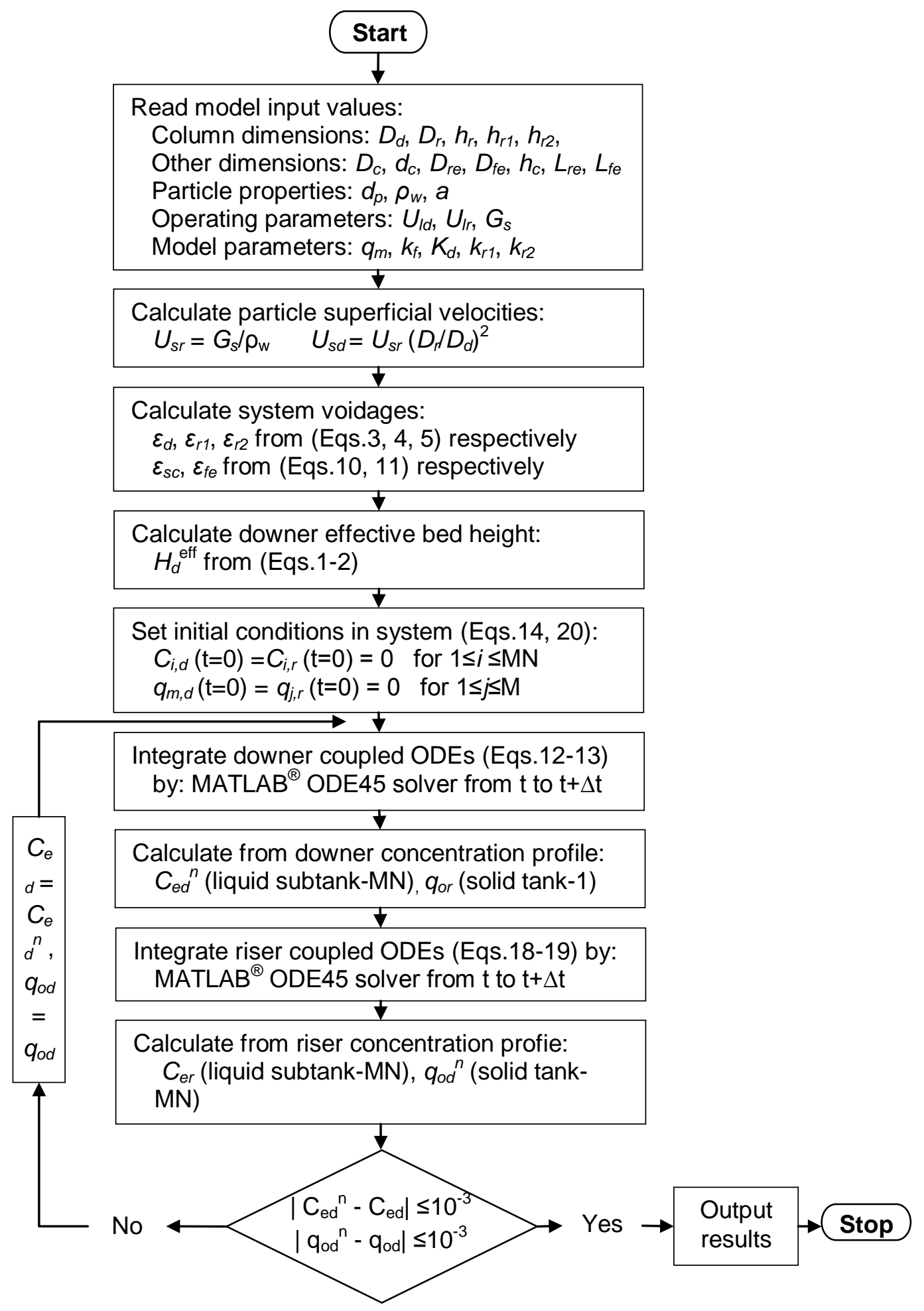

Figure 7. Algorithm for simulating the LSCFB system by tanks-in-series model 
(A)

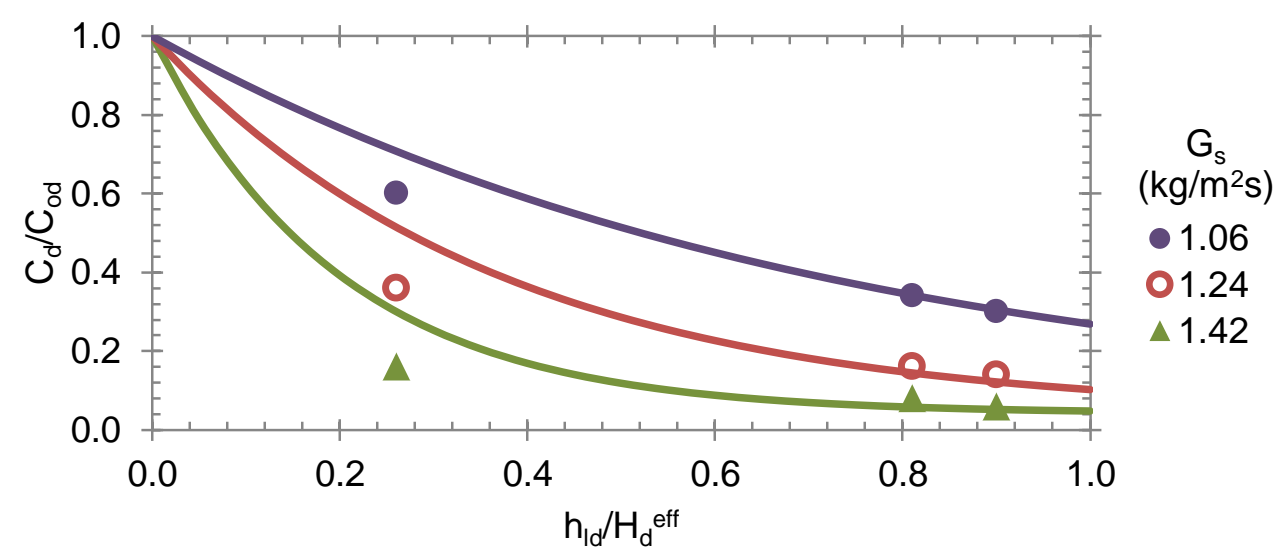

(B)

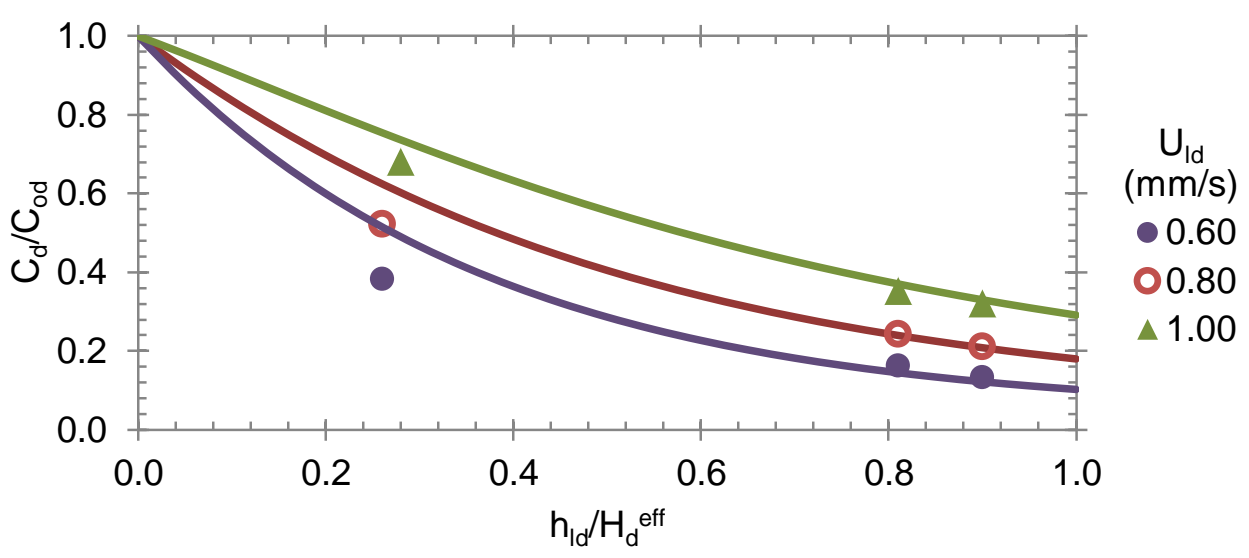

(C)

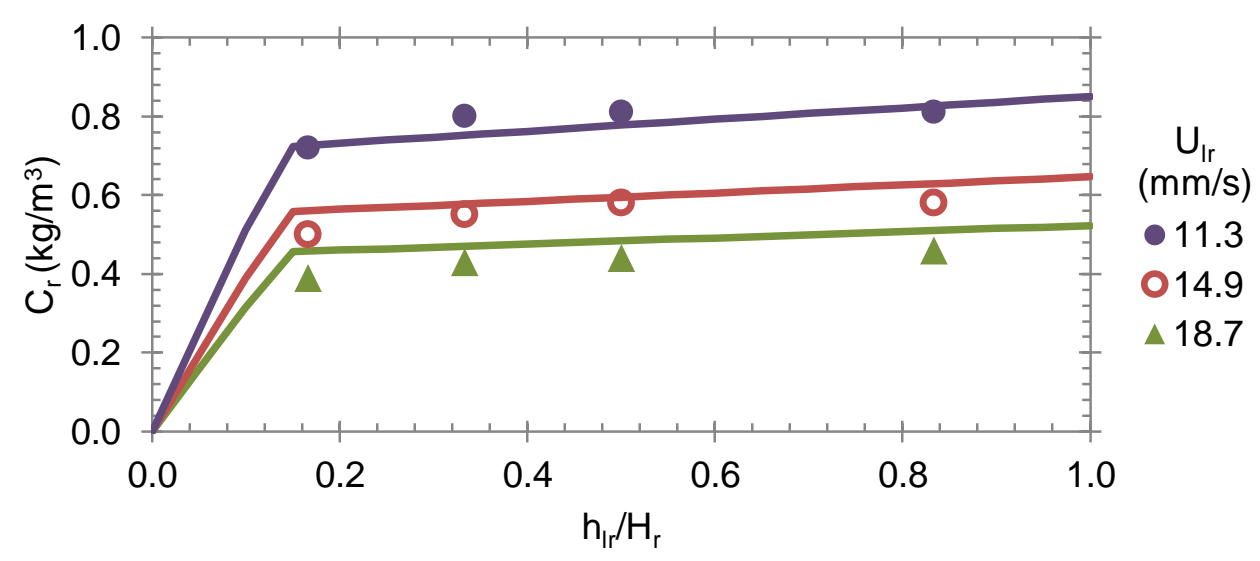

Figure 8. Experimental and predicted liquid phase protein concentration profiles under different (A) solids circulation rate $G_{s}\left(\mathrm{~kg} / \mathrm{m}^{2} \mathrm{~s}\right)$, (B) superficial liquid velocity in the downer $U_{l d}(\mathrm{~mm} / \mathrm{s})$, and (C) superficial liquid velocity in the riser $U_{l r}(\mathrm{~mm} / \mathrm{s})$ 
(A)

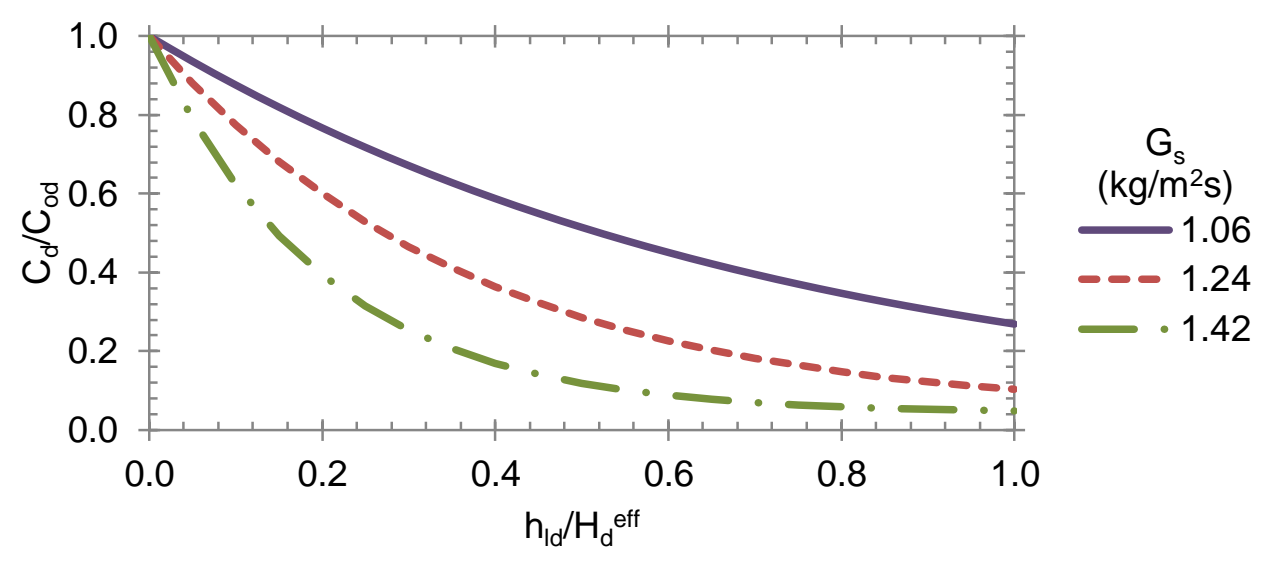

(B)

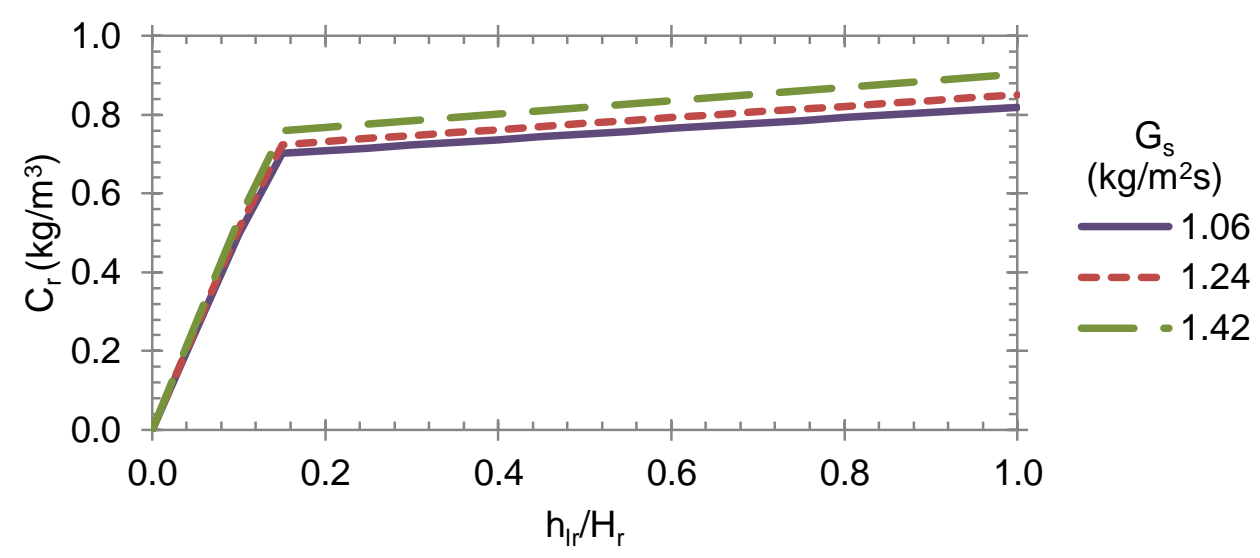

Figure 9. Liquid phase protein concentration profile in (A) the downer, and $(B)$ the riser under different solids circulation rate $G_{S}\left(C_{o c}=2 \mathrm{~kg} / \mathrm{m} 3, U_{l o}=0.6 \mathrm{~mm} / \mathrm{s}, U_{l l}=11.3 \mathrm{~mm} / \mathrm{s}, S=3 \mathrm{~kg}\right)$ 
(A)

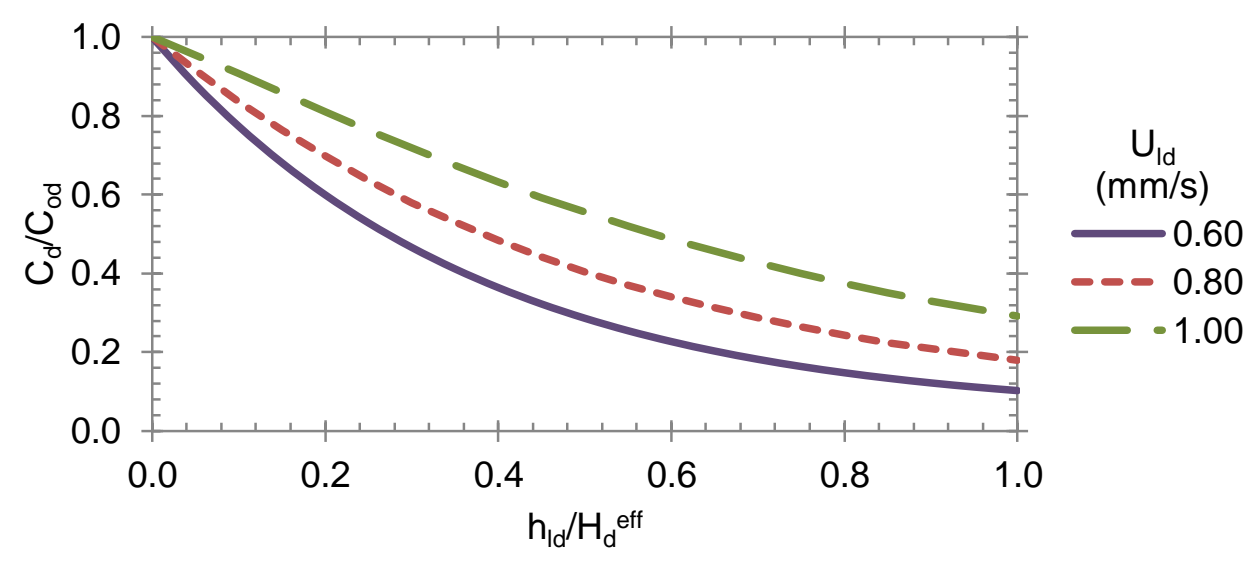

(B)

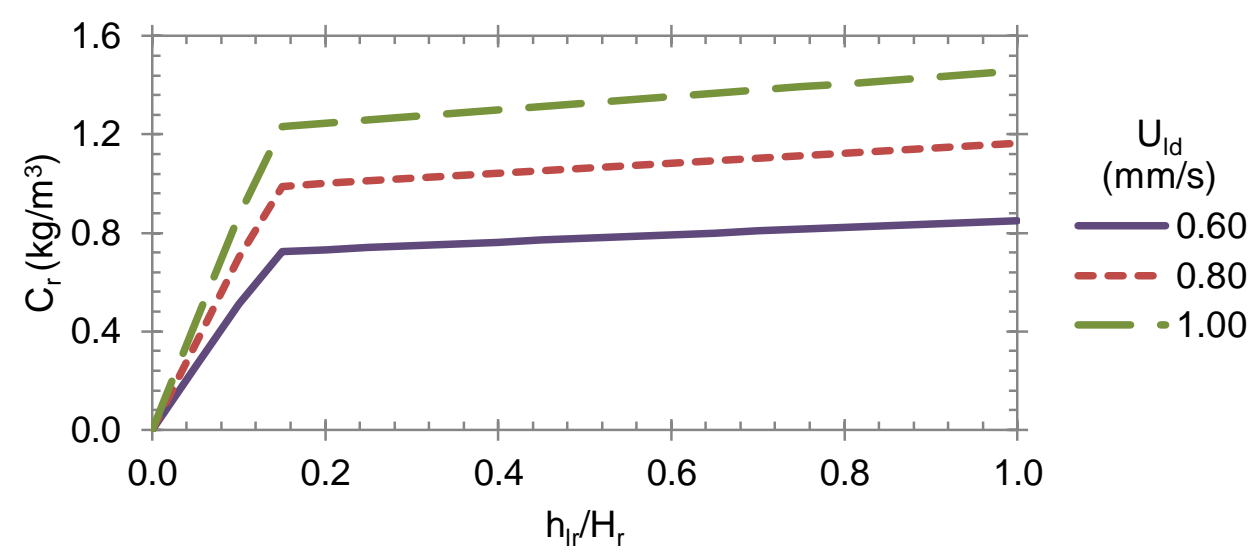

Figure 10. Liquid phase protein concentration profile in $(A)$ the downer, and $(B)$ the riser under different superficial liquid velocity in the downer $U_{l d}\left(C_{o o}=2 \mathrm{~kg} / \mathrm{m} 3, G_{s}=1.24 \mathrm{~kg} / \mathrm{m} 2 / \mathrm{s}\right.$, $U_{l l}=11.3 \mathrm{~mm} / \mathrm{s}, S=3 \mathrm{~kg}$ ) 
(A)

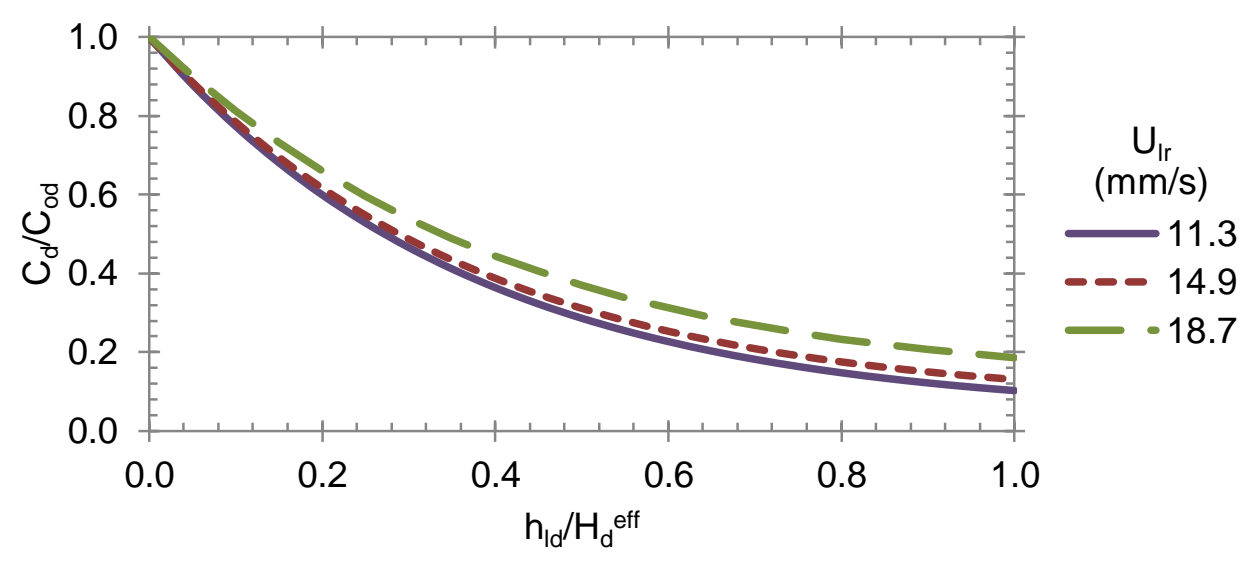

(B)

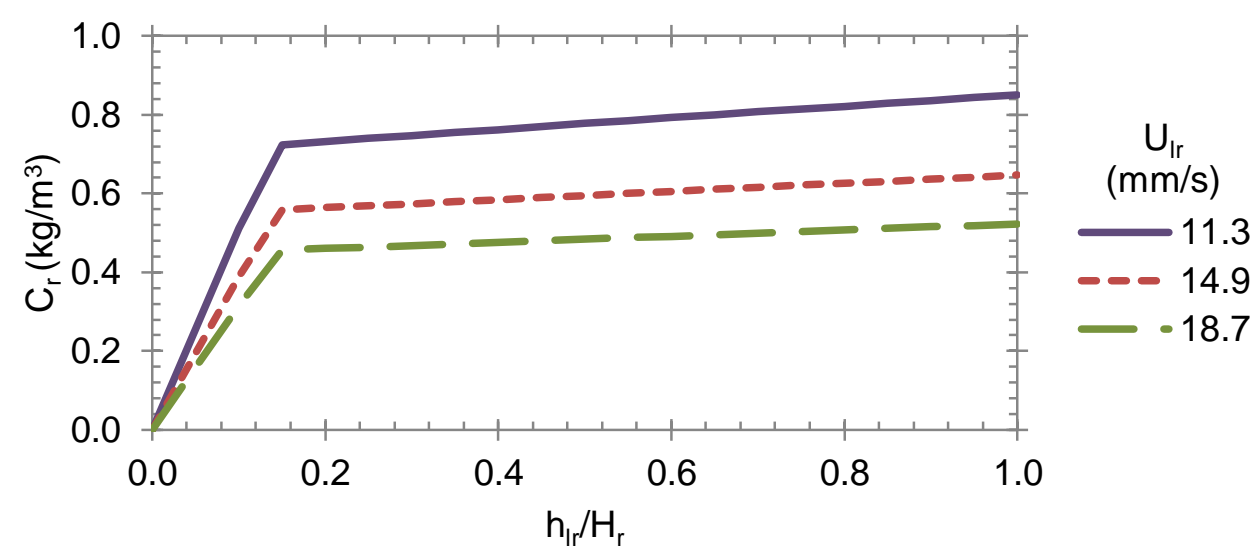

Figure 11. Liquid phase protein concentration profile in $(A)$ the downer, and $(B)$ the riser under different superficial liquid velocity in the riser $U_{l r}\left(C_{o d}=2 \mathrm{~kg} / \mathrm{m} 3, G_{s}=1.24 \mathrm{~kg} / \mathrm{m} 2 / \mathrm{s}, U_{l d}=0.60 \mathrm{~mm} / \mathrm{s}\right.$, $S=3 \mathrm{~kg}$ ) 
(A)

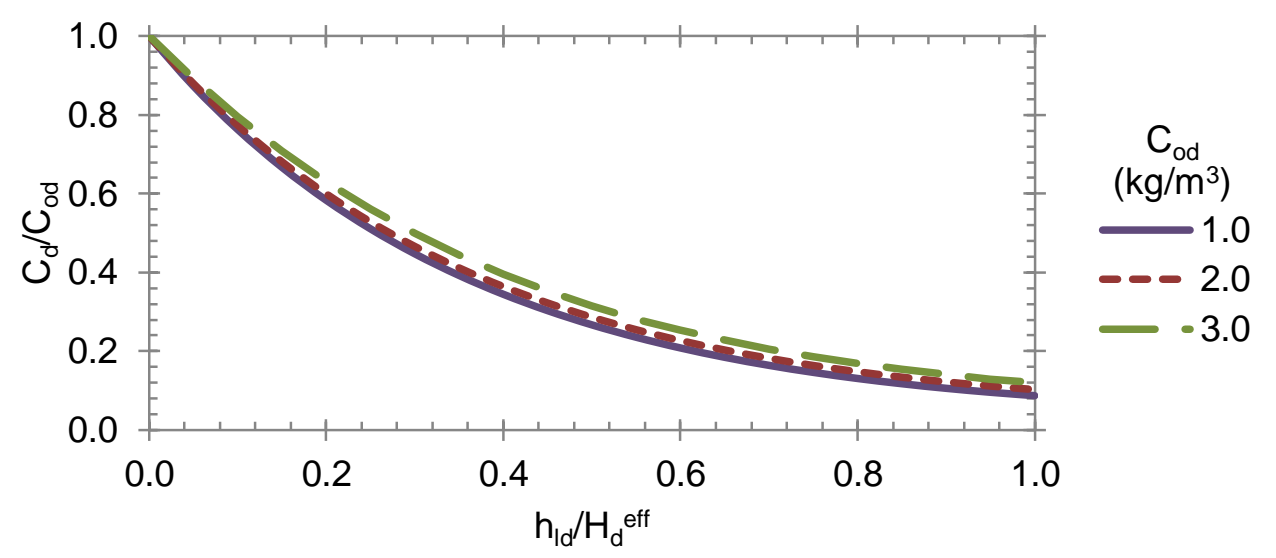

(B)

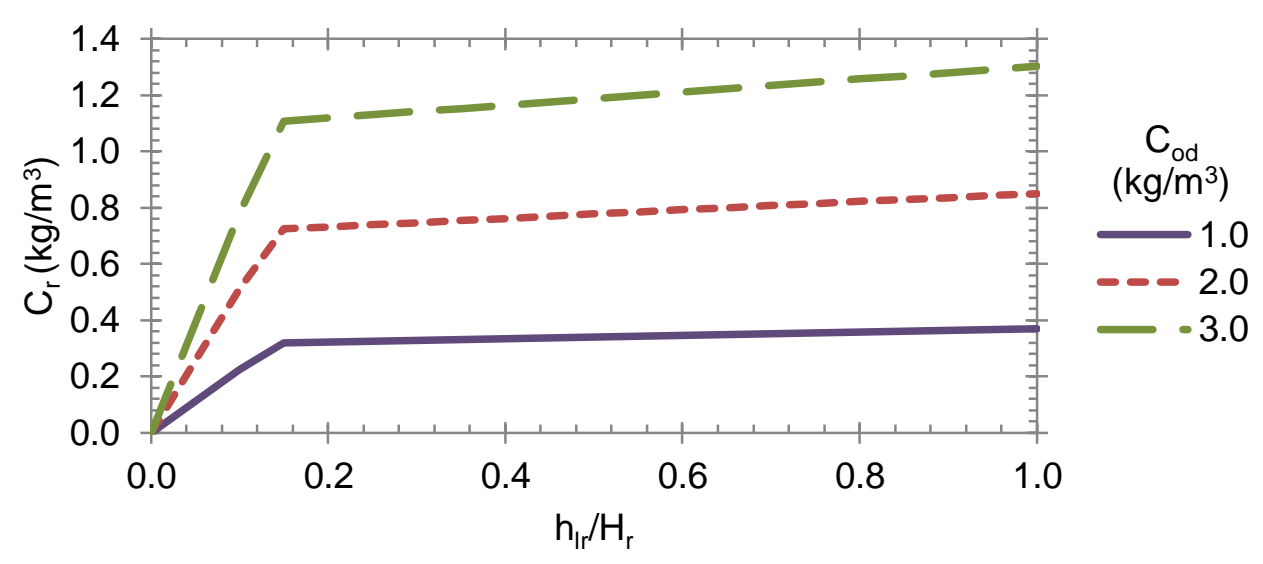

Figure 12. Liquid phase protein concentration profile in the downer under different feed concentration $C_{o d}\left(G_{s}=1.24 \mathrm{~kg} / \mathrm{m} 2 / \mathrm{s}, U_{l a}=0.60 \mathrm{~mm} / \mathrm{s}, U_{l l}=11.3 \mathrm{~mm} / \mathrm{s}, S=3 \mathrm{~kg}\right)$ 